Abstract-The effects of commercial fishing with crab pots on the physical condition of the snow crab (Chionoecetes opilio) and southern Tanner crab (C. bairdi) were investigated in the Bering Sea and in Russian waters of the Sea of Okhotsk. In crabs that were subjected to pot hauling, the presence of gas embolism and the deformation of gill lamellae were found in histopathological investigations. Crab vitality, which was characterized subjectively through observation of behavioral responses, depended on not only the number of pot hauls but also the time between hauls. Immediately after repeated pot hauls at short time intervals ( $\leq 3$ days), we observed a rapid decline in vitality of crabs. When hauling intervals were increased to $>3$ days, the condition of crabs did not significantly change. After repeated pot hauls, concentration of the respiratory pigment hemocyanin ([Hc]) was often lower in the hemolymph of crabs than in the hemolymph of freshly caught animals. Our research indicated that changes in $[\mathrm{Hc}]$ in crabs after repeated pot hauls were caused by the effects of decompression and not by starvation of crabs in pots or exposure of crabs to air. We suggest that the decrease in [Hc] in hemolymph of snow and southern Tanner crabs was a response to the adverse effects of decompression and air-bubble disease. The decrease in $[\mathrm{Hc}]$ in affected crabs may be a result of mechanisms that regulate internal pressure in damaged gills to optimize respiratory circulation.

Manuscript submitted 20 April 2012. Manuscript accepted 15 May 2013. Fish. Bull. 111:233-251 (2013). doi 10.7755/FB.111.3.3

The views and opinions expressed or implied in this article are those of the author (or authors) and do not necesarily reflect the position of the National Marine Fisheries Service, NOAA.

\title{
Effects of pot fishing on the physical condition of snow crab (Chionoecetes opilio) and southern Tanner crab (Chionoecetes bairdi)
}

\author{
Sergey I. Moiseev (contact author) ${ }^{1}$ \\ Svetlana A. Moiseeva ${ }^{2}$ \\ Tatyana V. Ryazanova ${ }^{3}$ \\ Anna M. Lapteva4 \\ Email address for contact author: moiseev@vniro.ru \\ 1 Department of Marine Commercial Invertebrates and Algae \\ Russian Federal Research Institute of Fisheries and Oceanography \\ 17 Krasnoselskaya Upper Street \\ Moscow, 107140 Russia \\ 2 Institute of Cell Biophysics \\ Russian Academy of Science \\ 3 Institutskaya Street \\ Pushchino, 142290 Russia \\ ${ }^{3}$ Kamchatka Research Institute of Fisheries and Oceanography \\ 18 Naberezhnaia Street \\ Petropavlovsk-Kamchatsky, 683000 Russia \\ ${ }^{4}$ Polar Research Institute of Marine Fisheries and Oceanography \\ 6 Knipovich Street \\ Murmansk, 183038 Russia
}

Commercial fishing for crabs in most countries is currently carried out with the use of baited crab pots. With this method of catching crabs, it is possible to reduce the effects of fishing on crab populations by sorting the catch, because females, sublegalsize males, and crabs with missing legs are returned to the sea alive. However, some of the discards die from body injuries and physiological stress associated with temperature changes and exposure to air. In surviving crabs, physiological imbalance and altered behavior can affect their ecological functions, such as predator avoidance, feeding, migration, and reproduction. Crabs are discarded in high proportions in relation to landings, and comprehensive information on the fate of the discards and their survival rate is required to make management decisions in a fishery. Prediction of discard survivability under a wide range of fishing conditions requires fundamental knowledge of the effects of catch-related stressors on crab physical condition.

To date, many studies have examined the effects of stressors, such as trauma from the hauling of pots, air exposure, and adverse temperatures, that are associated with capture, handling, and discarding of crabs (van Tamelen, 2005; Tallack, 2007; Stoner, 2009; Darnell et al., 2010). Decompression due to fast transport through the water column is one of the stressors that affect crabs during fishing with pots. Decompression results in air-bubble disease, the formation of gas bubbles in the blood and body fluids of crabs (Ryazanova, 2009). Gas bubbles form in the hemal system, organs, and tissues of crabs, causing hemal stasis, disruption and displacement of tissues. Although decompression is a constant and unavoidable adverse factor associated with pot fishing, relatively little attention has been paid to its effects on crab condition. Traditionally, decompression is not considered to be a substantial source of discard mortality (Stoner, 2012). However, gas-bubble disease caused by decompression could have prolonged deleterious effects on crab condition because air bubbles may persist in the body of a crab for a long time (Johnson, 1976). 
The subjects of this study were snow crab (Chionoecetes opilio) and southern Tanner crab (C. bairdi). Both species are heavily fished along the continental shelf of the Bering Sea and the Sea of Okhtosk of the Russian Federation. Snow and southern Tanner crabs are shallow-water species. They generally live from subtidal areas to a depth of $\sim 450 \mathrm{~m}$, although snow crab has also been found in much deeper water (Jadamec et al., 1999; Mihailov et al., 2003; Slizkin, 2010). In Russian waters, the snow crab inhabits environments with a temperature range from $-1.8^{\circ} \mathrm{C}$ to $7^{\circ} \mathrm{C}$. The southern Tanner crab is usually found in temperatures of $2-3^{\circ} \mathrm{C}$, avoiding bottom areas where a cold intermediate layer persists for a long time (Slizkin et al., 2001; Slizkin, 2010). In the area of overlap where the 2 species occur together, the abundance ratio of these crabs is strongly variable.

Unlike many other crustaceans, snow and southern Tanner crabs undergo a terminal molt before they become mature adults (Conan and Comeau, 1986; Comeau and Conan, 1992; Sainte-Marie et al., 1995). After their terminal molt, adult males of these species are available to pot fishing for only $0.5-3.0$ years because their carapaces become progressively fouled and ultimately deteriorate. Also after their terminal molt, crabs can no longer grow and regenerate lost limbs. Adult males that lack a limb are returned to the sea after a catch is sorted and because discarded crabs may be re-injured, the number of individuals that lack limbs increases in heavily fished populations. High-density aggregations of female snow and southern Tanner crabs are found to occur in different areas from those where males are caught. Therefore, female snow and southern Tanner crabs are rarely encountered in catches. The percentage of undersize males (carapace width $<100 \mathrm{~mm}$ ) usually does not exceed $5-10 \%$ of the total catch because of selectivity characteristics of trap gear. Therefore, damaged and "dirty" male snow and southern Tanner crabs may often compose a significant portion of the discards that occur in pot fishing. Although these crabs do not have market value, they may be involved in reproduction. It is probable that these crabs may be recaptured multiple times throughout their life and, therefore, may be exposed potentially to cumulative effects of fishing procedures.

This study was designed to investigate the effects of decompression and other stressors associated with pot hauling on the physical condition of adult male snow and southern Tanner crabs that had completed a terminal molt between 1.5 years and a few months previously. We conducted our experiments in the field. Crabs taken from the commercial catch were placed in commercial pots. The pots were then sunk and hauled back to the surface at different frequencies. With this approach, multiple factors in addition to decompression can affect the survivability of animals. These other factors include significant changes in environmental conditions during hauls, interaction of crabs with the gear, and exposure to the air. Therefore, to specifically assess the effects of decompression on crab physical condi- tion, histopathological changes in organs and tissues of crab caused by air-bubble disease were studied. Our approach was derived from the histological evidence of Johnson (1976), who found that the gills, heart, and antennal gland were the organs of blue crab (Callinectes sapidus) most severely affected by exposure to water supersaturated with air to simulate decompression effects. Bubbles persisted in the gills longer (more than a month) than in other organs of blue crab. We assumed that gill dysfunction caused by decompression would greatly affect the survivability of crabs after their release. Because of the logistical constraints of direct experimental research on gill function in the field, we investigated physiological parameters that could be used to estimate gill function disorders.

We selected hemocyanin $(\mathrm{Hc})$ as the indicator for the assessment of the effects of pot fishing on the physical condition of the snow crab and southern Tanner crab. $\mathrm{Hc}$ is a copper-containing respiratory pigment that increases solubility of oxygen $\left(\mathrm{O}_{2}\right)$ by a factor of $2-4$ and accounts for from $70 \%$ to more than $90 \%$ of the total protein concentration in the hemolymph of crustaceans (Truchot, 1992). Structural and functional variability of crustacean Hc has been shown to be of great importance for the adaptive condition of these organisms in response to metabolic changes and environmental stimuli (Bridges, 2001; Giomi and Beltramini, 2007). Therefore, we hypothesized that physiological alterations caused by impairment of respiratory function of the gills of snow and southern Tanner crabs could be correlated with changes in the structure and concentration of Hc. Plasma ion concentrations-for sodium ion $\left(\mathrm{Na}^{+}\right)$, potassium ion $\left(\mathrm{K}^{+}\right)$, chlorine ion $\left(\mathrm{Cl}^{-}\right)$, calcium ion $\left(\mathrm{Ca}^{2+}\right)$, and magnesium ion $\left(\mathrm{Mg}^{2+}\right)$-also were measured to examine ionoregulatory changes at the gills of affected crabs. During our experiments, factors other than decompression had an effect on crabs, including starvation and air exposure. Therefore, we also conducted experiments to assess the separate effects of starvation and air exposure on Hc.

We had the following objectives: 1) the investigation of histopathological deterioration of organs and tissues in snow and southern Tanner crabs subjected to pot hauling; 2) an analysis of the relationship between hauling intensity (the number and frequency of hauling events) and animal stress responses, including changes in behavior and biochemical parameters of hemolymph; and 3) an analysis of the utility of biochemical assays of Hc for prediction of survivability of snow and southern Tanner crabs subjected to hauling and discarding processes.

\section{Materials and methods}

\section{Study areas}

Snow crab and southern Tanner crab were collected during 5 fishing voyages in 2006, 2008, and 2010 in 
both the Bering Sea (Fig. 1) and the Sea of Okhtosk (Fig. 2). In the areas where we conducted our investigations, surface temperatures typically vary from $4^{\circ} \mathrm{C}$ to $12^{\circ} \mathrm{C}$ in summer and from $-1.5^{\circ} \mathrm{C}$ to $3^{\circ} \mathrm{C}$ in winter. Surface salinities generally vary between $32.2 \%$ and $33.0 \%$. In area I of the Bering Sea (Fig. 1) and in area I of the Sea of Okhtosk (Fig. 2), the 2 species occur together. At crab habitat depths of $50-350 \mathrm{~m}$, water temperatures range from -0.5 to $5.5^{\circ} \mathrm{C}$ throughout the year and salinity varies from $33.2 \%$ to $34 \%$.

\section{Crab capture and handling}

Collection of crabs and experimental work were carried out on a crab boat. The fishing gears that we used in this study were square pots of the "American" type and conical pots of the "Japanese" type (Moiseev, 2003). Both types of pots were covered with nylon-twine webbing (mesh size: $60-70 \mathrm{~mm}$ ). Crabs caught with commercial pots were maintained in large tanks supplied with natural seawater. Water temperatures during the holding period ranged from $4^{\circ} \mathrm{C}$ to $10^{\circ} \mathrm{C}$. These tanks were covered with tarpaulins to reduce stress effects of light on the crabs. All individuals were tagged with a piece of rubberized fabric marked with a unique number; a tag was attached to a crab claw with a plastic clip-strip. Because of the tendency for autotomy of limbs in southern Tanner and snow crabs, all manipulations were carried out quickly with the greatest possible care. During holding periods, no crabs died or showed signs of stress in the form of impaired reflexes (Moiseev et al., 2012).

For this study, experiments were limited to crabs that met the following criteria: 1) morphometrically mature males had completed a terminal molt between 1.5 years and a few months previously, according to criteria in Comeau and Conan (1992) and SainteMaria et al. (1995); 2) carapace width for snow crab was $110-150 \mathrm{~mm}$, and carapace width for southern Tanner crab was 120-155 $\mathrm{mm}$; 3) crabs were without apparent physical injuries or limb loss; and 4) crabs were in perfect condition as revealed with a vitality index (VI).

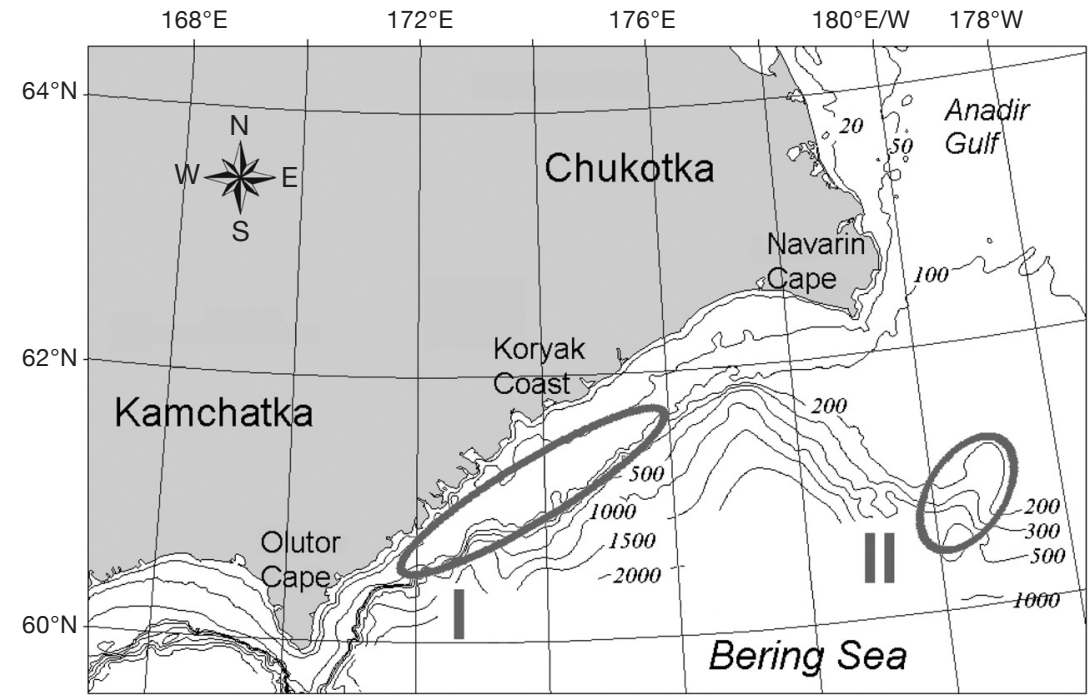

Figure 1

Map of areas where experiments and sample collection were conducted in the western Bering Sea in 2006-10 for our study of effects of commercial fishing with crab pots on the physical condition of the snow crab (Chionoecetes opilio) and southern Tanner crab (C. bairdi). Area I was near the Koryak Coast, and area II was the shelf and slope near Cape Navarin.

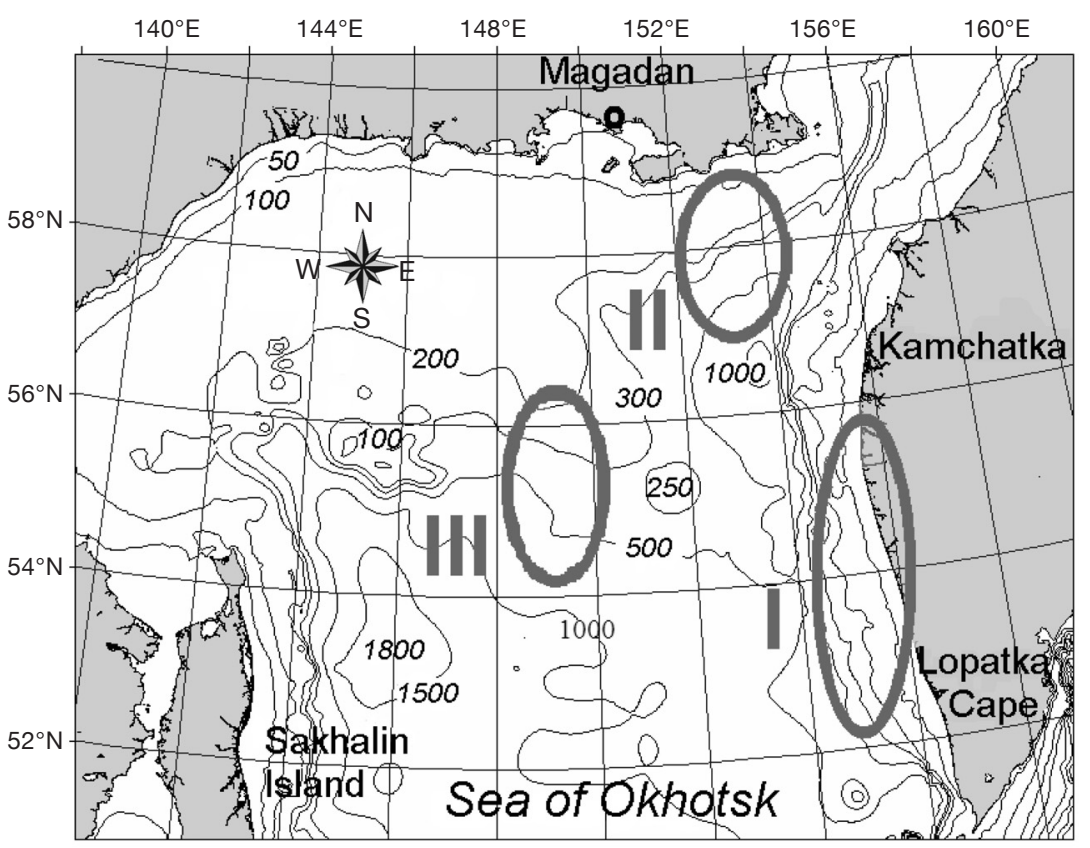

Figure 2

Map of areas where experiments and sample collections were conducted in the Sea of Okhtosk in 2006-10 for our study of effects of commercial fishing with crab pots on the physical condition of the snow crab (Chionoecetes opilio) and southern Tanner crab (C. bairdi). Area I was on part of the Western Kamchatka shelf, area II was on the shelf and continental slope on the beam of the Babushkin Gulf, and area III was in the central area of the northern Sea of Okhtosk. 


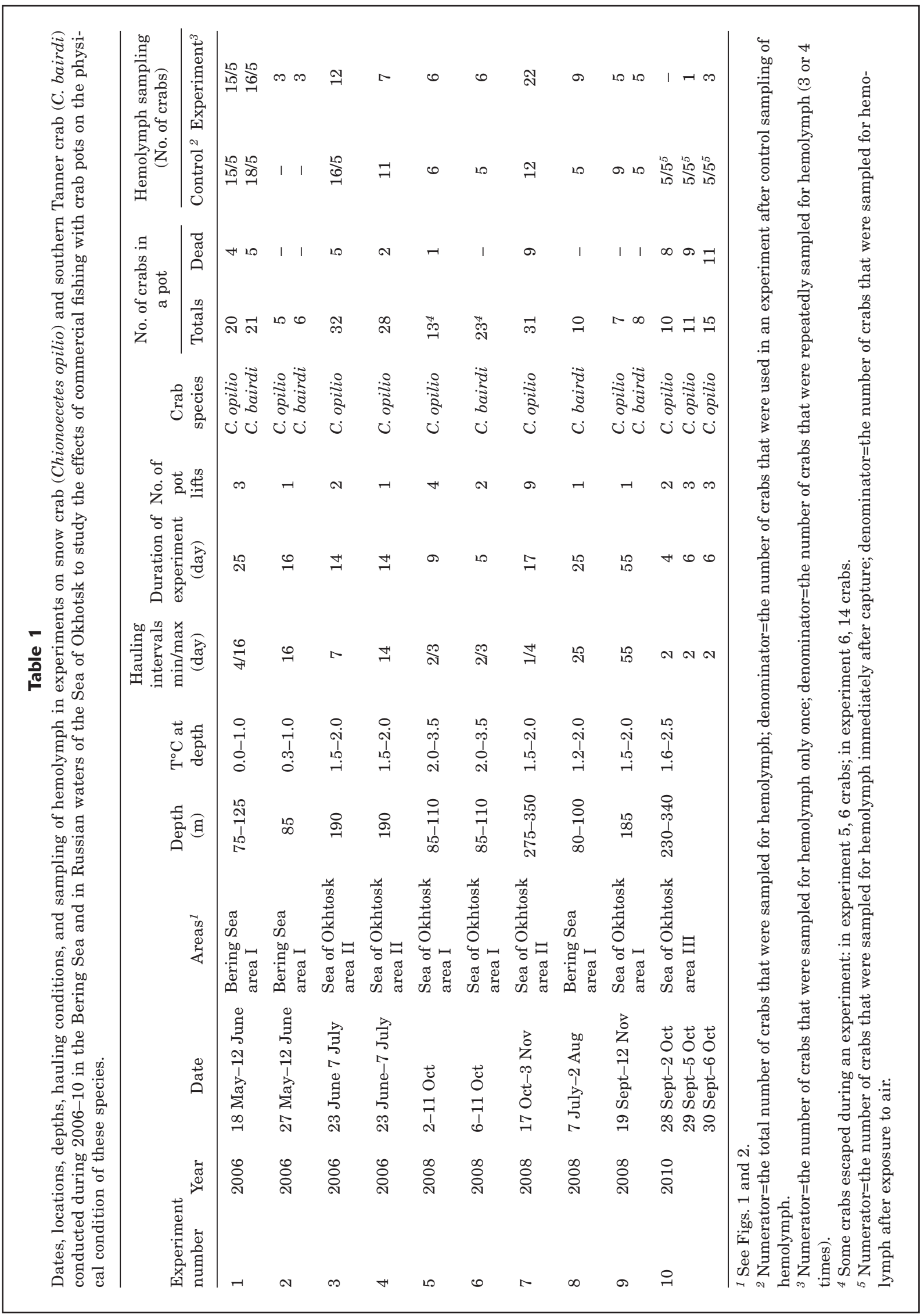




\section{Field experiments}

Effects of repeated pot hauling on crabs Snow crab and southern Tanner crab were placed in commercial crab pots. In experiments $1,3,5,6$, and 7 we used a single pot of the American-type (Table 1). Before deployment of the pots, the entrance tunnels of pots were sewn shut with webbing to prevent individuals in our experiment from escaping and other crabs and big animals (e.g., mammals, big fishes) from entering the pots from the environment. During our experiments, crabs were not fed. The pots were sunk and hauled back to the surface at different frequencies. During the preparation of pots for the next deployment, crabs were maintained in tanks with running seawater for periods from 10-15 min to 1-2 h. Experiments that involved repeated pot hauls were divided into 2 sets, depending on the hauling intervals: 1 ) short time intervals ( $\leq 3$ days) - experiments 5,6 , and 7-or 2) long time intervals ( $>3$ days)-experiments 1 and 3 (Table 1). Both control animals and those animals that were collected for experiments had been lifted to the water surface during capture. Hereafter, the number of pot lifts we specify includes only the lifts made during the experiment, unless otherwise stated.

Upon retrieval of pots, mortality was noted and the condition of each crab was monitored with the vitality index. Criteria for the index incorporated reflexes, spontaneous movements of appendages, and righting behavior (i.e., an animal's ability to turn from a ventrum-up position to normal orientation):

0 = no signs of life: no movement of legs or mouthparts; 1 = weak, slow movement of legs or maxillipeds, attempts at righting behavior, third pair of maxillipeds droop open and retract to cover small mouth parts when touched by pencil, chelae grab any object slightly and not for long (up to $30 \mathrm{~s}$ );

$2=$ moderate movement of legs, righting time of 10-60 s in water bath, fast movement of maxillipeds, chelae grab any object strongly and for long periods (up to $1.5 \mathrm{~min}$ );

3 = fast, active movement of legs, righting time of 5-40 $\mathrm{s}$ in water bath or on the sorting table, fast movement of maxillipeds, chelae grab any object strongly and for long periods ( $\geq 2 \mathrm{~min})$, threat display.

Effects of long-term starvation in pots on crabs In experiments $2,4,8$, and 9 , to investigate the effects of starvation, pots containing snow crab or southern Tanner crab were soaked (i.e., pots were deployed in the sea) for extended periods of time (14-55 days) (Table 1). Experiment 2 was combined with experiment 1 . In the course of experiment 1 , after the second lift of the pot, we added 5 freshly caught snow crab and 6 southern Tanner crab. The pot was lifted to the surface 16 days later; ocean conditions caused this long hauling interval (Table 1). At the end of all these experiments, the amount of meat in crab limbs was assessed by visual comparison of the slices of merus after boiling versus schematic representation of slices of merus in crab with varying degrees of meat content (Borisov et al., 2003).

Effects of long-term exposure to air on crabs Experiment 10 was designed to investigate the effects of long-term exposure to air on snow crab. It was replicated 3 times (Table 1). Snow crabs were kept out of the water on the deck from 6 to $8 \mathrm{~h}$ after capture. Animals were covered with a tarpaulin, which periodically was irrigated with seawater to protect the crabs from desiccation. Surface water temperatures were $6-7^{\circ} \mathrm{C}$, and air temperatures were $7-8^{\circ} \mathrm{C}$. Thereafter, $10-15$ individuals were placed in conical pots of the Japanese type, and these pots were deployed in the sea. In each repetition of the experiment we used a single pot which was hauled 2-3 times at intervals of 2 days.

\section{Sampling of hemolymph}

Sampling of hemolymph in crabs from commercial catches was completed within $30 \mathrm{~min}$ after a pot had appeared at the water surface, the length of time referred to hereafter as immediately after capture. Samples of hemolymph taken from crabs immediately after capture served as control samples. Most crabs from which control hemolymph samples were taken were discarded, but, in experiments 1 and 3, some crabs were used in the experiments after they had control samples of blood taken from them. In experiment 9, control samples of hemolymph were taken from crabs immediately after capture, as well as from the crabs exposed to air for 6-8 h before deployment of a pot. In most cases, crabs used for control samples of blood and crabs for our experiments were collected from the same commercial catches. In some cases, because of ocean conditions, crabs used for control samples of blood were collected from other commercial catches, but they always were collected from catches in the same fishing area at a distance $\leq 0.9 \mathrm{~km}$ from the experimental pots and always during the periods of our experiments. Upon retrieval of pots, during our experiments that involved repeated pot hauls, hemolymph was sampled from some of the crabs used in experiments; these individuals were discarded after blood was sampled. Only in experiments 1 and 3, crabs from which hemolymph samples were taken remain in the pot. In experiment 1 , in some individuals, blood was sampled repeatedly (3 or 4 times).

Hemolymph (3-5 mL) was quickly sampled from individual crabs with a syringe through the arthrodial membrane at the base of the fourth or fifth pair of legs. All manipulations were carried out quickly and carefully (the duration of crab exposure to air was not more than $10 \mathrm{~min}$ ). The hemolymph samples were frozen and stored below $-30^{\circ}$ while on board. For transport to the biochemistry laboratory, they were kept on ice. Before analysis, the samples of hemolymph were thawed at $4^{\circ} \mathrm{C}$ and centrifuged for $15 \mathrm{~min}$ at $12,000 \mathrm{rpm}$, and the supernatant was collected. In snow and southern Tan- 


\section{Table 2}

Dates, locations, depths, hauling conditions, and sampling for histology during repeated pot hauls in experiments conducted in 2010 to study the effects of commercial pot fishing on the physical condition of snow and southern Tanner crabs (Chionoecetes opilio and C. bairdi) in the Bering Sea and in Russian waters of the Sea of Okhotsk.

\begin{tabular}{|c|c|c|c|c|c|c|c|c|c|c|c|}
\hline \multirow[b]{2}{*}{$\begin{array}{l}\text { Experiment } \\
\text { number }\end{array}$} & \multirow[b]{2}{*}{ Year } & \multirow[b]{2}{*}{ Date } & \multirow[b]{2}{*}{ Areas $^{1}$} & \multirow[b]{2}{*}{$\begin{array}{l}\text { Depth } \\
\text { (m) }\end{array}$} & \multirow[b]{2}{*}{$\begin{array}{l}{ }^{\circ} \mathrm{C} \text { at } \\
\text { depth }\end{array}$} & \multirow[b]{2}{*}{$\begin{array}{c}\text { Hauling } \\
\text { intervals } \\
\min / \max \\
\text { (day) }\end{array}$} & \multirow[b]{2}{*}{$\begin{array}{l}\text { Duration of } \\
\text { experiment } \\
\text { (day) }\end{array}$} & \multirow[b]{2}{*}{$\begin{array}{l}\text { No. of } \\
\text { pot lifts }\end{array}$} & \multirow[b]{2}{*}{$\begin{array}{l}\text { Crab } \\
\text { species }\end{array}$} & \multicolumn{2}{|c|}{$\begin{array}{l}\text { Total number of } \\
\text { crabs sampled } \\
\text { for histology }\end{array}$} \\
\hline & & & & & & & & & & $\begin{array}{l}\text { Imme- } \\
\text { diately } \\
\text { after } \\
\text { capture }\end{array}$ & $\begin{array}{l}\text { During } \\
\text { repeated } \\
\text { pot } \\
\text { hauls }\end{array}$ \\
\hline 1 & 2010 & 4-11 Sept & $\begin{array}{l}\text { Bering Sea } \\
\text { area II }\end{array}$ & $170-260$ & $2.5-3.5$ & $2 / 3$ & 7 & 3 & $\begin{array}{l}\text { C. opilio } \\
\text { C. bairdi }\end{array}$ & $\begin{array}{l}3 \\
3\end{array}$ & $\begin{array}{l}5 \\
5\end{array}$ \\
\hline 2 & 2010 & $\begin{array}{l}28 \text { Oct- } \\
2 \text { Nov }\end{array}$ & $\begin{array}{l}\text { Sea of Okhtosk } \\
\text { area III }\end{array}$ & $230-340$ & $1.6-2.5$ & $2 / 3$ & 5 & 2 & C. opilio & 3 & 5 \\
\hline
\end{tabular}

${ }^{1}$ See Figures 1 and 2.

ner crabs, unlike in many other crabs, flocculent precipitate is formed during blood coagulation and can be removed easily by centrifugation.

\section{Histological examinations}

To examine the histopathological condition of organs and tissues in crabs that were subjected to repeated pot hauls, tissue samples were taken from both crab species during repeated pot hauls at time intervals of 2-3 days (Table 2). In each experiment, samples were taken from 5 individuals used in that experiment and from 3 freshly caught individuals that served as control animals. Fragments of internal organs were fixed for 24-40 h with Davidson's fluid (Bell and Lightner, 1988) prepared in seawater. After fixation, the samples were transferred to $70 \%$ alcohol, in which they were kept in the laboratory. This material was further treated with standard histological techniques: samples were dehydrated in an alcohol series of increasing concentrations, clarified with chloroform, and embedded in paraffin. Sections were stained with Meyer's hematoxylin-eosin (Johnson, 1980) and slides were examined under an Olympus Al-2 light microscope (Olympus Corp., Tokyo, Japan ${ }^{1}$ ).

\section{Ionic composition of hemolymph}

Colorimetric tests (DiaSys Diagnostic Systems GmbH, Holzheim, Germany) were used to measure concentrations of $\mathrm{Ca}^{2+}\left(\left[\mathrm{Ca}^{2+}\right]\right), \mathrm{Mg}^{2+}\left(\left[\mathrm{Mg}^{2+}\right]\right)$, and $\mathrm{Cl}^{-}\left(\left[\mathrm{Cl}^{-}\right]\right)$in hemolymph. Concentration of $\mathrm{K}^{+}\left(\left[\mathrm{K}^{+}\right]\right)$and $\mathrm{Na}^{+}\left(\left[\mathrm{Na}^{+}\right]\right)$ were determined by flame photometry (FLAPHO 4, Carl Zeiss, Jena, Germany).

\footnotetext{
${ }^{1}$ Mention of trade names or commercial companies is for identification purposes only and does not imply endorsement by the National Marine Fisheries Service, NOAA.
}

\section{Hemocyanin concentration}

The $[\mathrm{Hc}]$ in the hemolymph of individual crabs was estimated with an established spectrophotometric method (Nickerson and Van Holde, 1971; deFur et al., 1990). An aliquot of serum was diluted by $50 \mathrm{mmol}$ $\mathrm{L}^{-1}$ Tris $\mathrm{HCl}$, containing $10 \mathrm{mmol} \mathrm{L}^{-1}$ EDTA, $\mathrm{pH} 8.9$ (1:39). The absorbance of the resultant mixture was measured at $338 \mathrm{~nm}$. The [Hc] was calculated with the extinction coefficient given by Nickerson and van Holde (1971), by assuming an average molecular weight of $75 \mathrm{kDa}$ for subunits of hemocyanins (Hc's) from snow crab and southern Tanner crab.

\section{Electrophoresis}

To estimate the molecular weight of the different subunits of the Hc's from snow crab and southern Tanner crab, sodium dodecyl sulfate polyacrylamide gel electrophoresis (SDS/PAGE) was carried out on whole hemolymph by using the discontinuous buffer system of Laemmli (1970) on slab gels. The stacking gel was made of $4.0 \%$ and $2.7 \%$ acrylamide and bis-acrylamide, respectively, with a $\mathrm{pH}$ of 6.8 , and the resolving gel was made of $10.0 \%$ and $2.7 \%$, respectively, with a $\mathrm{pH}$ of 8.8 . The samples $(10 \mu \mathrm{g})$ were run at $4^{\circ} \mathrm{C}$ and 20 $\mathrm{mA}$ with a tris-glycine buffer $(\mathrm{pH} 8.3)$. The gels were stained with Coomassie Brilliant Blue (Bio-Rad Laboratories, Hercules, CA).

\section{Copper content in the hepatopancreas}

In experiments 6 and 7, which involved repeated pot hauls at short time intervals ( $\leq 3$ days), samples of hepatopancreas were dissected, after blood was sampled (Table 1). Samples of hepatopancreas also were dissected from southern Tanner crab after starvation in 
the pot for 55 days in experiment 9 (Table 1). Samples of hepatopancreas were frozen in plastic bags, stored, and transported in the same manner as that used for the samples of hemolymph. The hepatopancreas copper content of individual crabs was determined by atomic absorption spectrophotometry (Shimadzu AA-6800, Shimadzu Corp., Kyoto, Japan) with the method of Kirichenko et al. (2005). In experiments 6 and 7, copper content was determined in samples of hepatopancreas from only those individual snow crab and southern Tanner crab in which $[\mathrm{Hc}]$ was twice as low as the mean $[\mathrm{Hc}]$ in the crabs immediately after capture.

\section{Results}

\section{Dependence of crab vitality on haul frequency}

Our experiments, in which we examined the physiological capacity of snow crab and southern Tanner crab to survive the variable environment associated with haul and return to the sea revealed that the condition of an animal was strongly dependent on the time interval between pot lifts. During repeated pot hauls at short time intervals ( $\leq 3$ days) in experiments 5,6 , and 7 , we observed a rapid reduction in reflex responses and locomotor activity in crabs. After 2-3 lifts in pots, the vitality of crabs was close to the minimum (VI=0-1). In experiment 7 , the total number of pot lifts was 9 . After the first 2 lifts, VI=1-2; after the third to sixth lifts, VI=0-1; and after the last 2 lifts, VI approached 0 . During repeated pot hauls at long time intervals $(>3$ days) in experiments 1 and 3 , the condition of the crabs did not significantly change or was only moderately suppressed (VI=2-3). At time intervals of more than a week between pot hauls (experiments 2, 4, 8, and 9), the condition of most crabs was not significantly different from the condition of freshly caught animals.

\section{Changes in hemocyanin concentration depending on hauling interval}

Long intervals $(>3$ days) In experiment 1,3 pot lifts were made: the first lift on the fifth day, the second lift on the ninth day, and the third lift only on the 25th day because of ocean conditions (Table 1). We observed a significant decrease in $[\mathrm{Hc}]$ in the hemolymph of snow crab and southern Tanner crab during this experiment: both in crabs in which blood was sampled only once (Fig. 3, A and $\mathrm{B}$ ) and in crabs in which blood was sampled more than once (Fig. 4, A and B). The main decrease in [Hc] occurred during the time that elapsed between the capture of crabs and the second pot lift. During the next 16 days and up to the 25th day of the experiment, further decreases in $[\mathrm{Hc}]$ were observed but were not significant (Fig. 3, A and B).

In experiment 3 , mean $[\mathrm{Hc}]$ in the hemolymph of snow crab used in our experiments decreased by $51 \%$, after the first pot lift on the seventh day, compared

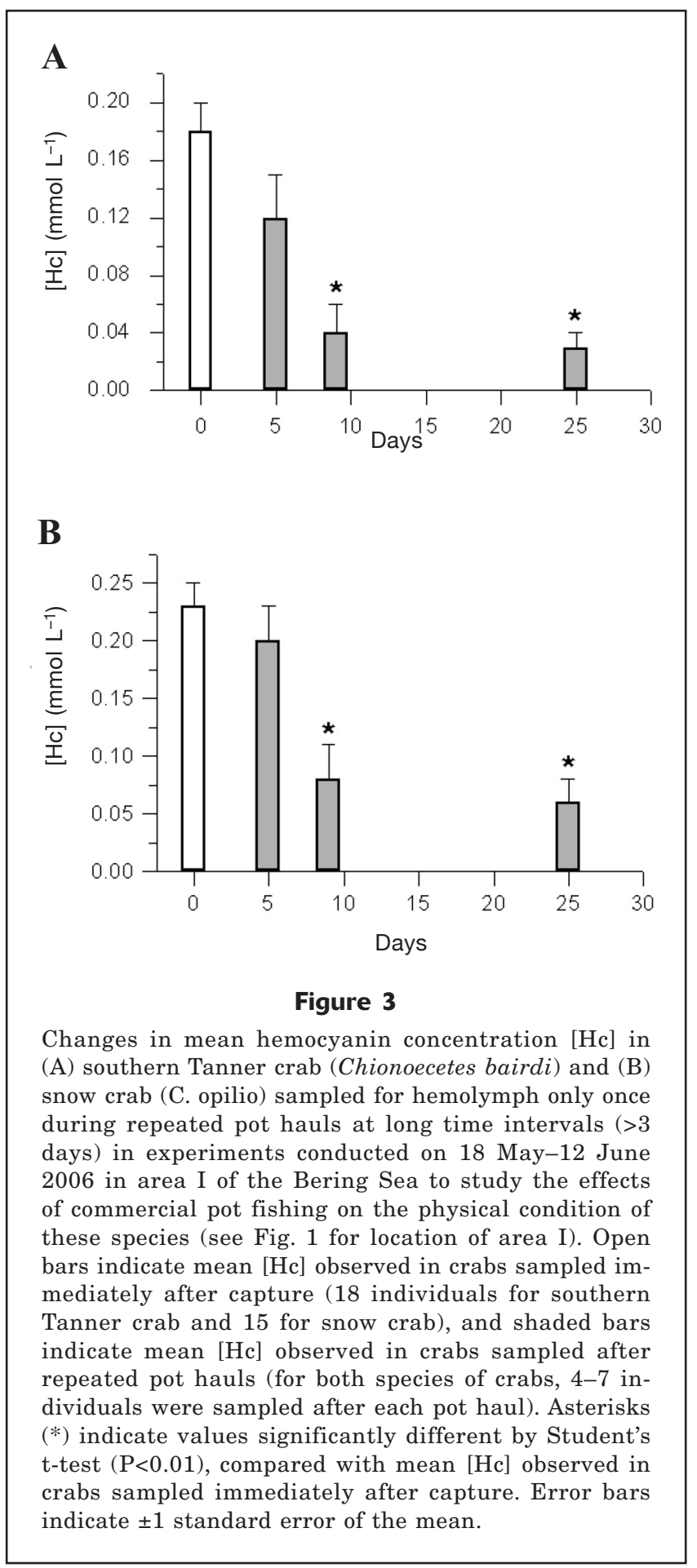

with the mean $[\mathrm{Hc}]$ found in control samples collected immediately after capture, and the difference was significant (Student's $t$-test, $P<0.01$ ). After the second pot lift on the 14th day, large variations in $[\mathrm{Hc}]$ in the hemolymph of snow crab were observed, and the difference between experimental and control animals, therefore, was not significant (data not shown). 


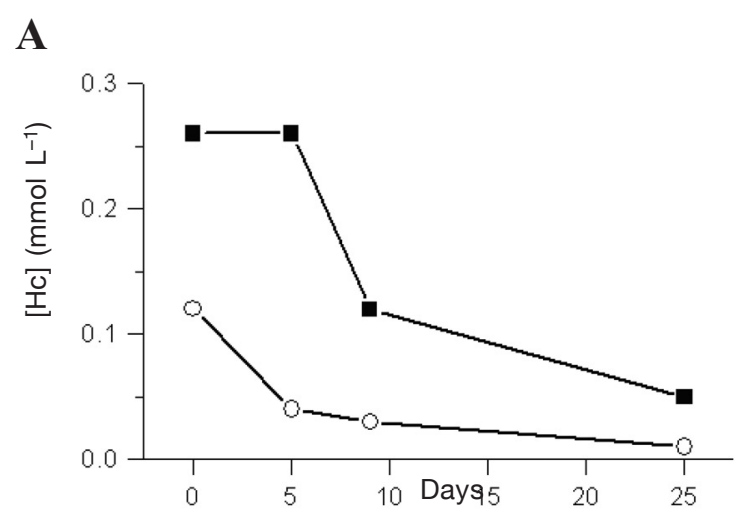

B

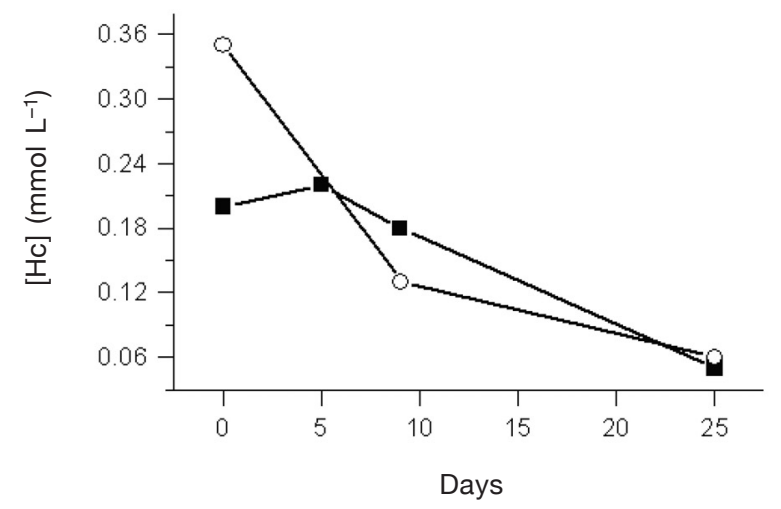

Figure 4

Changes in hemocyanin concentration $[\mathrm{Hc}]$ in (A) southern Tanner crab (Chionoecetes bairdi) and (B) snow crab (C. opilio) repeatedly sampled for hemolymph during multiple pot hauls at long time intervals ( $>3$ days) in experiments conducted on 18 May-12 June 2006 in area I of the Bering Sea to study the effects of commercial pot fishing on the physical condition of these species (see Fig. 1 for location of area I).

Short time intervals ( $\leq 3$ days) In experiment 7 , the planned time intervals between lifts were 1-2 days. However, because of ocean conditions, they ranged from 1 to 4 days. The total number of pot lifts was 9, and hemolymph was not sampled after the third, fifth, and seventh lifts (Table 1). Large variations in [Hc] in the hemolymph of snow crab were observed after the second pot lift until the end of the experiment (Fig. 5). In one-third of experimental animals, [Hc] was markedly lower, by $50 \%$ or more, than mean [Hc] observed in control crabs, although, in the remaining animals used in the experiment, [Hc] did not differ significantly from Hc levels in control samples.

Experiments 5 and 6 were similar to but not as prolonged as experiment 7 . In both of these experiments, large variations in [Hc] in snow and southern Tanner crabs were observed. In experiment 5 , in approximately

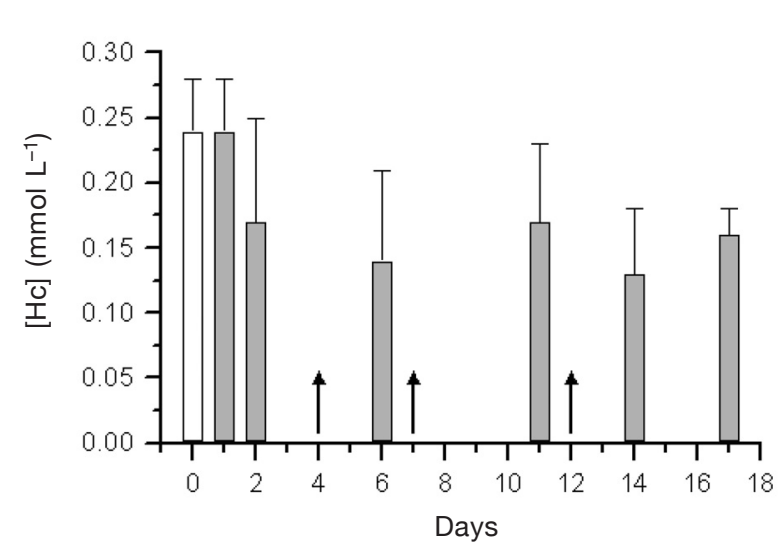

Figure 5

Changes in mean hemocyanin concentration [Hc] in snow crab (Chionoecetes opilio) during repeated pot hauls at short time intervals ( $\leq 3$ days) in experiments conducted on 17 October-3 November 2008 in area II of the Sea of Okhtosk to study the effects of commercial pot fishing on the physical condition of these species (see Fig. 2 for location of area II). In experiment 7, ocean conditions extended time intervals to 1-4 days rather than the planned 1-2 days. Open bar indicate mean $[\mathrm{Hc}]$ observed in crabs sampled immediately after capture (number of individuals was 12), and shaded bars indicate mean $[\mathrm{Hc}]$ observed in crabs sampled after repeated pot hauls (the number of individuals sampled after each pot haul was 3-5). Error bars indicate \pm 1 standard error of the mean. Arrows indicate third, fifth, and seventh pot lifts when sampling of blood was not carried out.

one-half of individual snow crab, [Hc] was markedly lower, by $80 \%$ or more, than mean $[\mathrm{Hc}]$ in control crabs. In experiment 6 , in approximately one-half of individual southern Tanner crab, [Hc] was markedly lower, by $70 \%$ or more, than mean [Hc] in control crabs. In both of these experiments, in one-half of experimental animals, [Hc] did not differ significantly from Hc levels in control samples (data not shown).

\section{Effects of long-term starvation on crabs in pots}

In experiment 2 and 4 , the duration of pot soaking was 16 and 14 days, respectively. At the end of these experiments, mean [Hc] in hemolymph of snow crab and southern Tanner crab did not significantly differ from mean [Hc] in hemolymph of control crabs immediately after capture (data not shown).

In experiment 8 , the duration of pot soaking was 25 days. At the end of this experiment, mean [Hc] in hemolymph of southern Tanner crab was slightly lower than [Hc] in control crab immediately after capture, but the mean difference between experimental and control animals was not significant (Student's $t$-test, $P>0.05$ ) (Fig. 6A). 


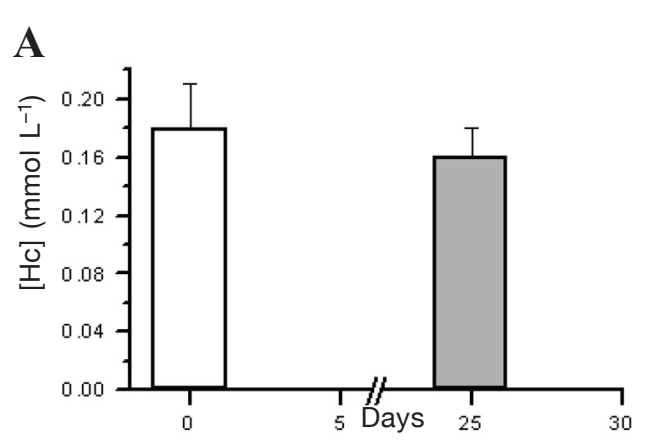

B

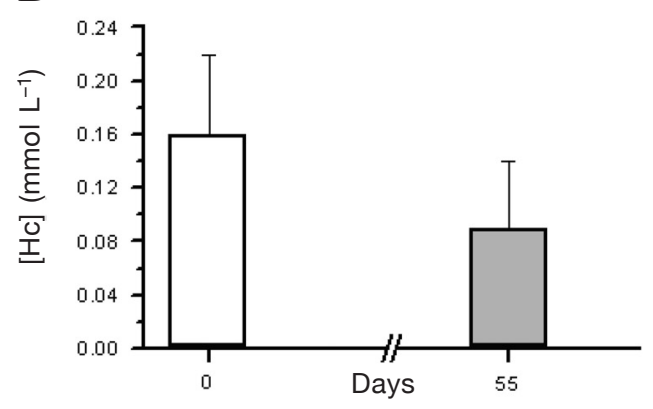

C

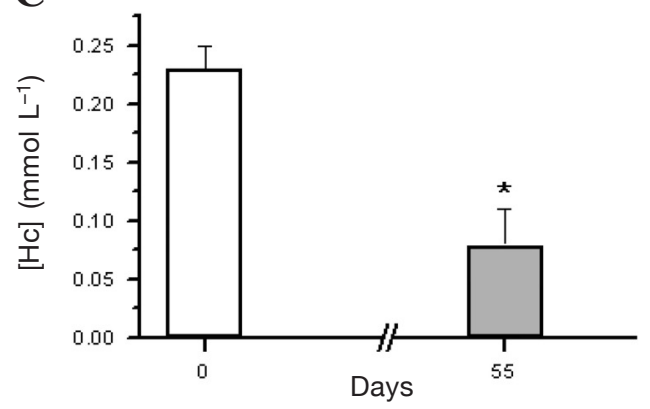

Figure 6

Changes in mean hemocyanin concentration [Hc] in snow crab (Chionoecetes opilio) and southern Tanner crab (C. bairdi) after starvation in crab pots. Open bars indicate mean [Hc] observed in crabs sampled immediately after capture (9 individuals for snow crab and 5 for southern Tanner crab for each experiment), and shaded bars indicate mean [Hc] observed in crabs sampled after starvation (5 individuals for snow crab and 9 and 5 for southern Tanner crab for experiments with pot soaking time of 25 days and 55 days, respectively): (A) southern Tanner crab, pot soaking time $=25$ days, Bering Sea (area I), 7 July-2 August 2008; (B) southern Tanner crab, pot soaking time $=55$ days, 19 September-12 November 2008, Sea of Okhtosk (area I); and (C) snow crab, pot soaking time $=55$ days, 19 September-12 November 2008, Sea of Okhtosk (area I). An asterisk (*) indicates values were significantly different by Student's $t$-test $(P<0.001)$, compared with mean $[\mathrm{Hc}] \mathrm{ob}$ served in crabs immediately after capture. Error bars indicate \pm 1 standard error of the mean.
In experiment 9 , pots soaked for 55 days. At the end of this experiment, mean [Hc] in southern Tanner crab decreased by $44 \%$ compared with mean [Hc] in control crab immediately after capture (Fig. 6B), but the difference between the experimental and control animals was not significant (Student's $t$-test, $P>0.05$ ). In snow crab, mean [Hc] decreased by $67 \%$ compared with mean [Hc] in control crab (Fig. 6C), and the difference was significant (Student's $t$-test, $P<0.001$ ).

During experiment 4, 2 crab died. At the end of the remaining experiments, all experimental animals were alive and their vitality was high $(\mathrm{VI}=2-3)$. At the end of all experiments, the weight of experimental crabs and the amount of meat in crab limbs did not change significantly.

\section{Effects of long-term exposure to air on snow crab}

In experiment 10, after long-term exposure to air, the vitality of snow crab was low $(\mathrm{VI}=0-1)$ and mean $[\mathrm{Hc}]$ in these animals was comparable with the mean [Hc] in control crabs immediately after capture. After longterm exposure to air, most of the crab that were subjected to the pot-hauling process were dead after the first pot-hauling event. Some individuals were able to survive $2-3$ pot hauls (Table 1 ). Samples of hemolymph could be obtained from crab only after the first pot haul. [Hc] in hemolymph of those animals was comparable with the mean $[\mathrm{Hc}]$ in control crab immediately after capture.

\section{Histological investigations}

In our experiments both control and experimental animals were hauled from the water in the pot at least once and, therefore, gas embolism was observed in hearts and gills of both control and experimental animals during gross examination of dissected crabs (Fig. 7). Histopathological investigations found intact and deformed gill lamellae in both experimental and control individuals of snow crab and southern Tanner crab (Fig. 8, A and B; Fig. 9, A-C). Hemolymph spaces of deformed gill lamellae were greatly expanded, sometimes in the form of vesicular swellings, or, conversely, the opposite walls of lamellae were stuck together (Fig. 9A). Often the connections of pillar cells in dilated parts of lamellae were torn (Fig. 9B). Marginal canals had irregular shapes or were swollen and filled with a large number of hemocytes. Opposite walls of lamellae under the marginal canals, as a rule, were stuck together (Fig. 9C). Gas bubbles and aggregations of hemocytes were found in the myocardia of individuals of both experimental and control snow crab and southern Tanner crab. Similar changes often were observed in antennal glands, in skeletal muscles, and in connective tissues of the stomachs and guts of crabs. Infiltrations of hemocytes and different-size, melanized inclusions often were found in the gill lamellae of both control and experimental crabs (Fig. 9D). We were unable to find or show dependence 


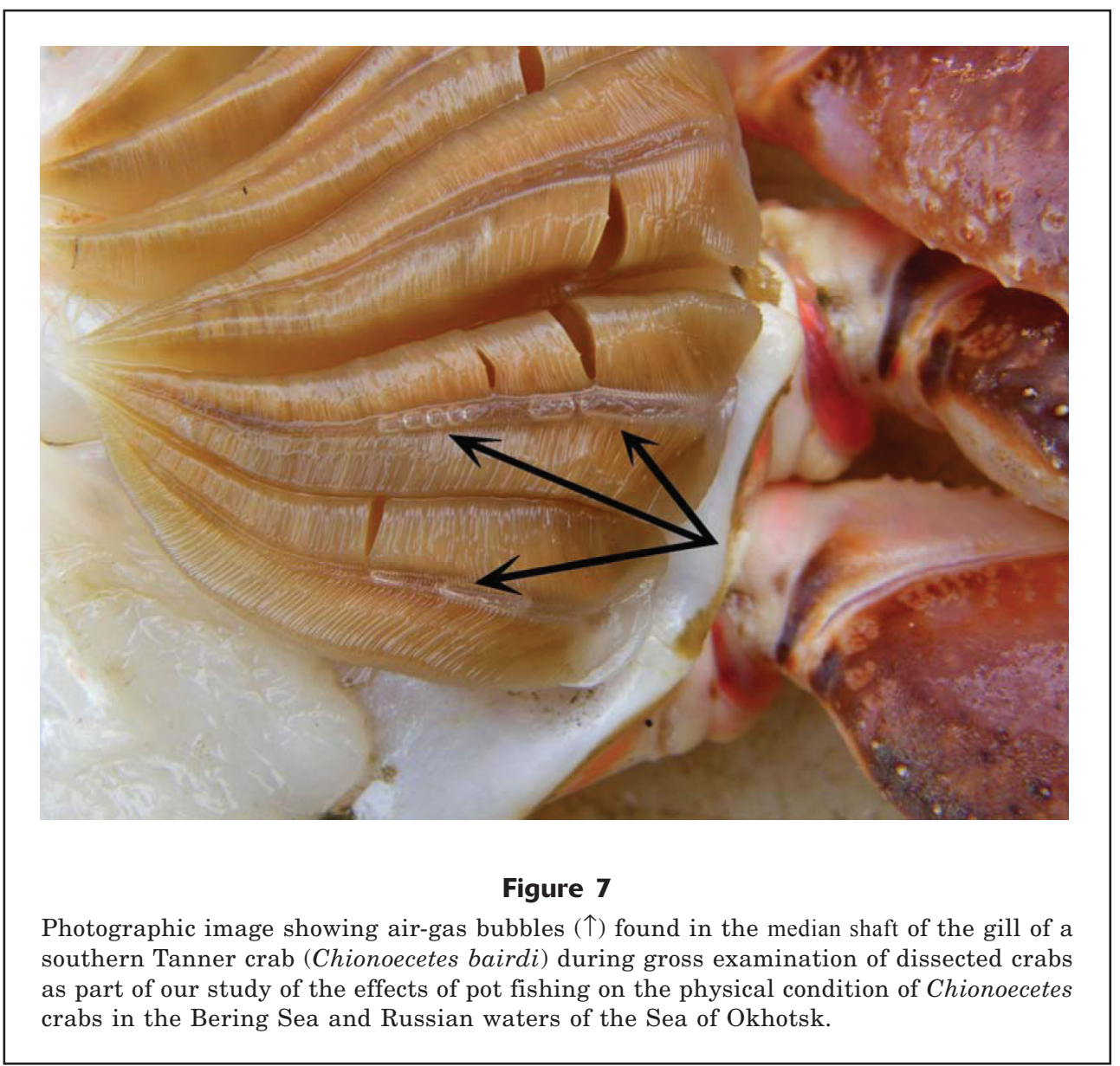

of the degree of damage in gills on the number of lifts (Table 2).

\section{Copper content in the hepatopancreas}

A significant difference in hepatopancreas copper levels between control and experimental individuals (Student's $t$-test, $P<0.05$ ) was observed in experiment 9 , where long-term starvation of southern Tanner crab in a crab pot was investigated (Table 3). There were no significant differences in hepatopancreas copper levels between control and experimental snow crab and southern Tanner crab in experiments 6 and 7, which involved frequent lifts of crab pots.

\section{Ionic composition of hemolymph}

The ionic composition of hemolymph from snow and southern Tanner crabs under different experimental conditions was investigated (Table 4). In experiment 1 , a significant decrease in $\left[\mathrm{K}^{+}\right]$was observed in hemolymph from snow crab (Student's $t$-test, $P<0.01$ ) and southern Tanner crab (Student's $t$-test, $P<0.05$ ) after 3 pot hauls. In experiment 9 , a significant decline in $\left[\mathrm{K}^{+}\right]$ was observed in hemolymph from snow crab after starvation in a pot for 55 days (Student's $t$-test, $P<0.05$ ).

\section{Subunit composition of hemocyanins}

In the Hcs from snow crab and southern Tanner crab, 4 and 3 differently migrating polypeptide chains, respectively, were found in the SDS/PAGE experiment. In our investigations, the patterns of bands obtained by SDS/ PAGE in both crab species did not change under different experimental conditions (data not shown).

\section{Discussion}

\section{Effects of pot fishing on crab vitality}

In most studies on the effects of pot fishing on crabs, the main focus was mortality of animals. Experiments in other studies that involved repeated pot hauls showed that mortality of deepwater beni-zuwai crab (Chionoecetes japonicus) and triangle Tanner crab (Chionoecetes angulatus) depended on molt stage, and mortality of new-shell crabs was greater than mortality of old-shell animals (Koblikov, 2004; Vasilyev and Kli- 


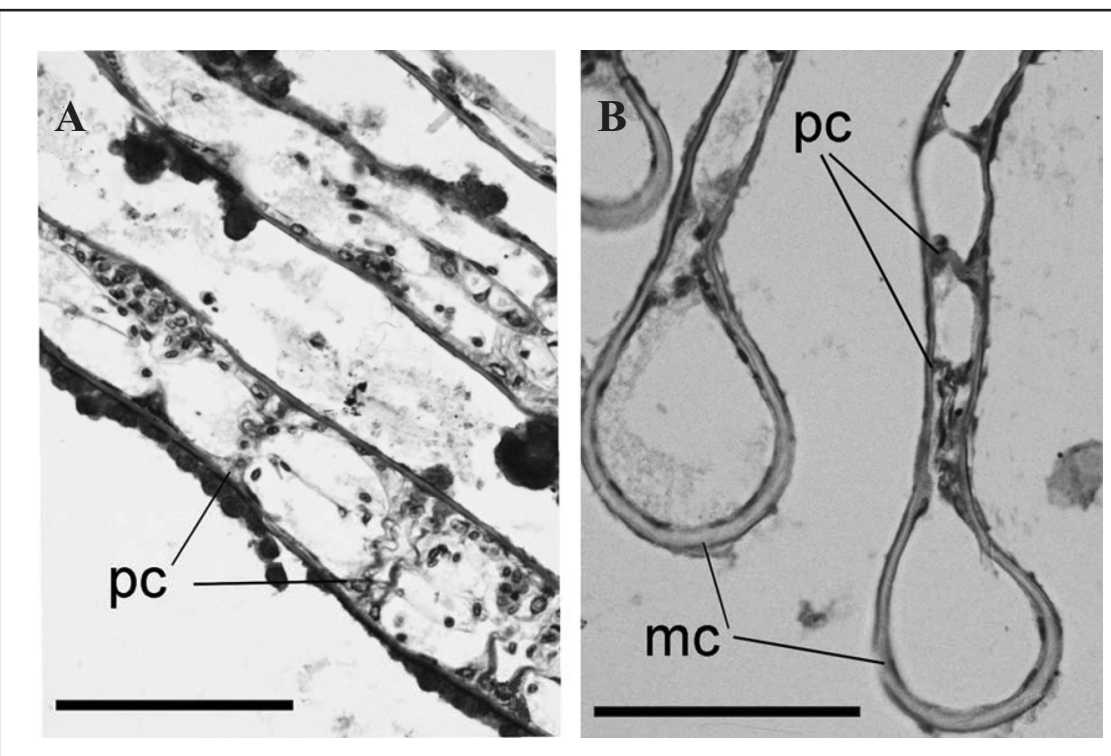

Figure 8

Light micrographs of normal gills in snow crab (Chionoecetes opilio) and southern Tanner crab (C. bairdi) from our study of the effects of pot fishing on the physical condition of these species: (A) distal part of lamellae in a southern Tanner crab and (B) apical part of lamellae in a snow crab. Hematoxylin and eosin staining was used. Abbreviations: pc=pillar cells; $\mathrm{mc}=$ marginal canal. Scale bar $=100 \mu \mathrm{m}$.

by predatory amphipods. It can be assumed that, within the size range of crabs kept in the pots in our experiments (see the Materials and methods section), aggressive interaction between crabs and cannibalism were not significant factors in the mortality of animals. Cannibalism in snow crab occurs only between individuals of significantly different sizes (Dutil et al., 1997; Lovrich and SainteMarie, 1997). Our research on the attractiveness of dead crabs as bait showed that they did not attract individuals of their own species (senior author, unpubl. data).

Therefore, mortality of crabs in our experiments was not a reliable indicator of the physiological disorders in crabs. Reversible physiological disorders did not result in death of the animals, and mortality of crabs often was caused by trauma from gear. During the course of our experiments in the field, the vitality of each crab was monitored with a VI. Vitality, or general health status of crabs, can be characterized subjectively

nushkin, 2011). Tallack (2007) investigated mortality of red deepsea crab (Chaceon quinquedens) in different hauling conditions (i.e., crabs hauled every $24 \mathrm{~h}$, after intervals of 4 or 8 days) and found that crab hauled to the surface every $24 \mathrm{~h}$ showed significantly greater mortality than crab retrieved after 4 or 8 days.

In our study, experiments on snow and southern Tanner crabs, like all experiments described in the previous paragraph, were conducted as actual field operations with minimal control of external variables, including air exposure, changes in temperature, light, and physical injuries. In our experiments, mortality of crabs was induced by blood sampling. For example, in experiment 1 , mortality was $20 \%$ for snow crab and $24 \%$ for southern Tanner crab, and all the dead crabs that could be identified from their remains were crabs from which samples of blood were taken 1 or 2 times. This mortality most likely resulted from predation of amphipods (e.g., Orchomenella affinis) that were attracted to the wounds caused by sampling. However, in experiment 3 , mortality rates did not differ significantly between crabs from which samples of blood were taken (17\%) and crab from which no blood samples were taken $(15 \%)$.

Another substantial source of crab mortality in our experiments was trauma associated with gear encounters. Externally visible injuries to the carapace were found often in dead animals that had encountered gear. In all dead crabs, soft tissues were quickly eaten away by observing or testing behavioral or whole-animal responses (reflex actions). The severity of physiological disorders in crabs is related directly to changes in vitality of crabs (Stoner, 2009, 2012).

The haul and return of pots to the seabed caused shifts in the homeostasis of crabs, leading to changes in health status of the animals. In turn, the health status of the animals influenced their physical responses to stress. We used adult male snow crab and southern Tanner crab that had completed a terminal molt between 1.5 years and a few months previously. Therefore, the vulnerability of animals in our research to external factors was less influenced by intrinsic variables, such as processes of growth, maturation, or molt stage, than it would have been if we had used immature or egg-producing female crabs.

A temporary shift of physiological homeostasis in crabs caused by the process of pot hauling may be corrected by the natural regulatory capacity of an organism or by adaptive physiological responses. The investigations on the mortality of snow crab in crab pots carried out by Ivanov and Karpinski (2003) revealed that crab weakened by frequent pot hauls could restore natural physiological conditions (i.e., locomotor activity and righting behavior) if the time intervals between successive pot lifts were increased. In their experiments, it was found that after 2 pot lifts at time intervals of 2 days, the surviving crabs were greatly weakened. However, the condition of animals improved significantly af- 

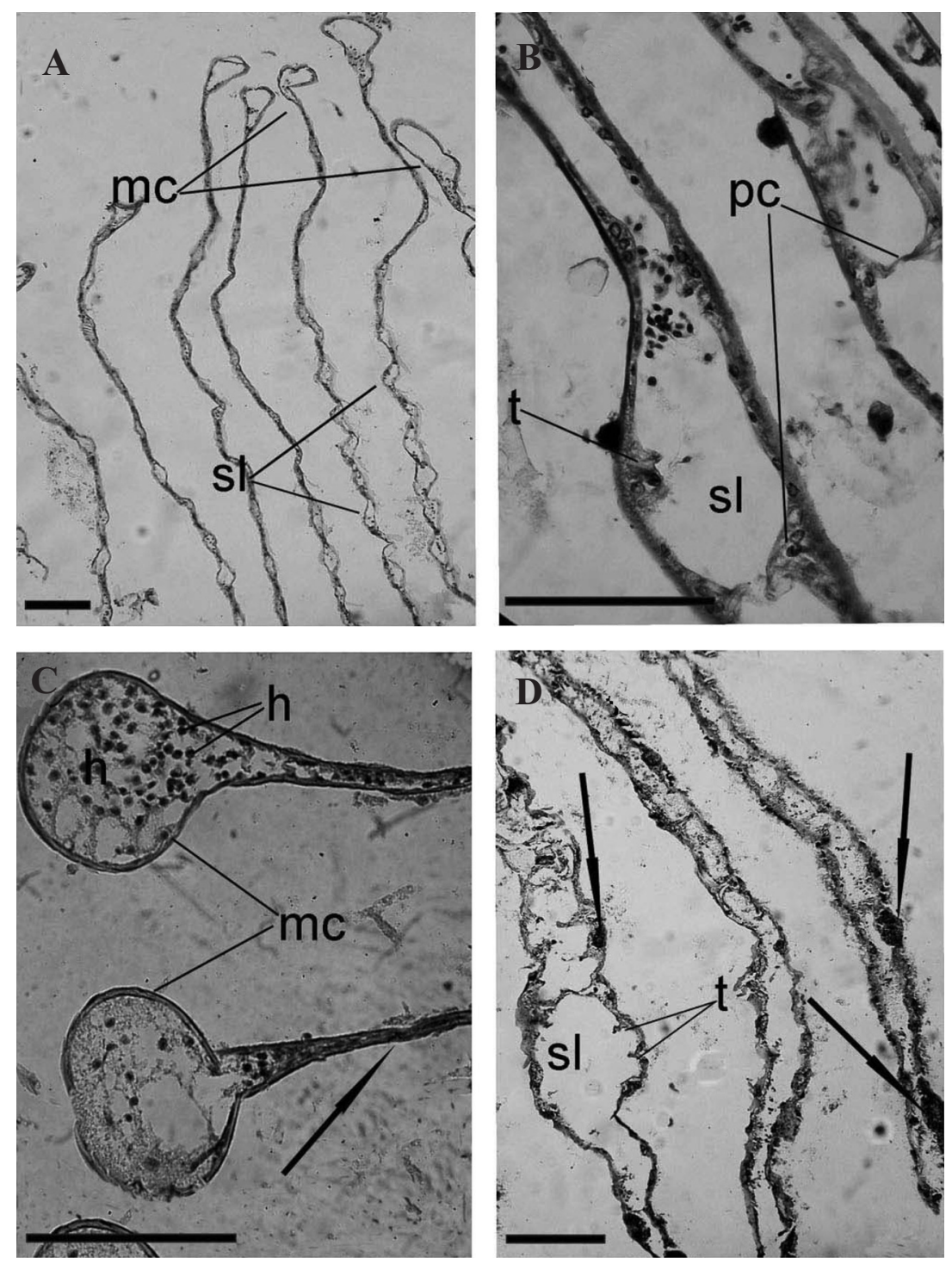

Figure 9

Light micrographs of damages to gills in snow crab (Chionoecetes opilio) and southern Tanner crab (C. bairdi) from our study of the effects of pot fishing on the physical condition of these species: (A) deformation of lamellae; note the irregular shape of the marginal channels and vesicular swellings; (B) torn connections of pillar cells in the dilated parts of the lamellae; (C) swollen marginal canals filled with hemocytes and collapsed lamellae walls (marked by arrow); and (D) melanized inclusions in lamellae (arrows); note the deformation of lamellae and torn connections of pillar cells. Hematoxylin and eosin stains were used. Abbreviations: $\mathrm{mc}=$ marginal canal; $\mathrm{sl}=$ swelling of lamellae; $\mathrm{pc}=$ normal pillar cells; $\mathrm{t}=$ torn pillar cells; and $\mathrm{h}=\mathrm{hemocytes}$. Scale bar=100 $\mu \mathrm{m}$.

animals was strongly dependent not only on the number of but also on the length of time between pot lifts. During repeated pot hauls at short intervals $(\leq 3$ days), we observed a rapid decline in vitality of crabs. When we increased hauling intervals to $>3$ days, the condition of crabs did not change significantly or was suppressed only moderately.

\section{Effects of pot fishing on hemocya- nin concentration}

In our experiments, [Hc] was selected as an objective measurement for the assessment of the effects of pot fishing on the physical condition of snow crab and southern Tanner crab. In addition to serving as a practical and simple indicator, it can be easily related to respiratory function, which can be impaired because of air exposure and gill disorders that result from fishing and handling operations.

The [Hc] in crustacean hemolymph is determined by the balance between anabolism and catabolism of the protein. The turnover rate of crustacean $\mathrm{Hc}$ is thought to be slow in usual steady-state conditions. Halftimes for clearance of ${ }^{125}$ I-labeled Hc have been reported to be 25.5 and 36 days in American lobster (Homarus americanus) and $\mathrm{Ca}$ ribbean spiny lobster (Panulirus argus) (Senkbeil and Wriston, 1981). A more rapid synthesis of Hc can be induced by various environmental factors, such as changes of ambient salinity (Gilles, 1977; Péqueux et al., 1979) and by moderate chronic hypoxia (Hagerman and Baden, 1988; deFur et al., 1990; Spicer and Baden, 2001).

A decrease in $[\mathrm{Hc}]$ in hemolymph of crustaceans may be caused by starvation. It has long

ter the pot had soaked for 4 days. After an additional 8 days of pot soaking, crabs recovered completely: all animals were alive and their condition did not significantly differ from the condition of freshly caught animals.

In our experiments, comparisons of the different hauling conditions also revealed that the vitality of been noted that $[\mathrm{Hc}]$ is related to the nutritional state of crustaceans under natural conditions (Dall, 1974; and references therein), leading some researches to suggest that, in times of plenty, Hc serves not only as an $\mathrm{O}_{2}$ carrier but also as a storage protein. Terwilliger (1998) noted, "This may occur, although storing ex- 


\section{Table 3}

Copper concentration, $[\mathrm{Cu}]$, measured in micrograms (g wet weight ${ }^{-1}$ ), in samples of the hepatopancreas of snow crab $(C h i$ onoecetes opilio) and southern Tanner crab (C. bairdi) under different experimental conditions. $[\mathrm{Cu}]$ values are means $( \pm 1$ standard error $[\mathrm{SE}]$ ).

\begin{tabular}{|c|c|c|c|c|}
\hline \multirow[b]{2}{*}{ Experimental conditions } & \multicolumn{2}{|c|}{ C. bairdi $i^{1}$} & \multicolumn{2}{|c|}{ C. opilio ${ }^{2}$} \\
\hline & {$[\mathrm{Cu}]$} & No. of samples & {$[\mathrm{Cu}]$} & No. of samples \\
\hline Immediately after capture & $5.5(1.3)$ & 7 & $0.92(0.07)$ & 7 \\
\hline Starvation in a crab pot within a period of 55 days & $37.3(18.5)^{*}$ & 5 & - & - \\
\hline Repeated pot hauls at short time intervals ( $\leq 3$ days) & $17.0(12.1)$ & 6 & $2.6(1.8)$ & 6 \\
\hline
\end{tabular}

119 September-12 November 2008, 6-11 October 2008, Sea of Okhtosk (area I).

217 October-3 November 2008, Sea of Okhtosk (area II).

* Significantly different from that of individuals sampled immediately after capture $(P<0.05)$, Student's $t$-test.

cess nutrients as circulating oligomeric proteins seems a bit expensive" (p. 1088). Nonetheless, studies have shown that concentrations of total protein and Hc in hemolymph steadily decrease in starved animals under laboratory conditions (Hagerman, 1983; and references therein). However, it is probable that some of these effects were a result not of reduction in the absolute amount of protein but of dilution of the protein. Dall (1974) showed that blood protein concentration in the longlegged spiny lobster (Panulirus longipes) decreased with starvation within 4 weeks, but this decrease was actually due to the increase in blood volume as solid tissues were metabolized. Djangmah (1970) observed that blood protein decreased from $7.9 \mathrm{~g} \mathrm{~L}^{-1}$ to $2.55 \mathrm{~g} \mathrm{~L}^{-1}$ and that there was a progressive accumulation of copper in the hepatopancreas of the common shrimp (Crangon crangon) after 23 days of starvation. He suggested that the stored copper came from catabolism of Hc, which is, therefore, rendered usable as an energy source in a starving animal. Laboratory studies showed that the changes of [Hc] elicited by food availability occurred gradually over periods of many days (Djangmah, 1970; Hagerman, 1983). However, Spicer and Strömberg (2002) demonstrated that starvation had a significant effect on [Hc] in northern krill (Meganyctiphanes norvegica) over the course of a few hours ( $\leq 10)$ under laboratory conditions. They used laboratory studies to interpret changes in krill [Hc] that they observed during the diel vertical migration of northern krill. Spicer and Strömberg (2002) attributed such dramatic decreases in [Hc] in starved individuals to the high metabolic rates of northern krill.

During our experiments, crabs were not fed because it was not possible to control the amount of food consumed by individuals. Any food placed in crab pots is quickly eaten by predatory amphipods, which also are thought to attack weak or injured crabs (Ivanov and Karpinski, 2003). Because the duration of our experiments was up to several weeks, there was a need to determine to what extent the fall in crab [Hc] was re- lated to the forced starvation of animals during the experiments. In our experiments on the effects of starvation on crabs, at pot soaking durations of 14,16 , and 25 days, $[\mathrm{Hc}]$ in snow crab and southern Tanner crab did not change significantly compared with [Hc] in crabs immediately after capture (Fig. 6A). A significant drop in mean [Hc] between crabs before and crabs after soaking was observed only in experiment 9 , in which crabs soaked in a pot for 55 days (Fig. 6, B and C). We, therefore, assume that starvation had no significant effect on the changes in the [Hc] in crabs in all experiments that involved repeated pot hauls because, in these experiments, [Hc] significantly changed over the course of a few days.

A rapid decrease in [Hc] in crustaceans may be associated with the processes of anaerobic metabolism, which is one of the major physiological responses to $\mathrm{O}_{2}$ deprivation. Increases of lactate and bicarbonate-carbonic acid during anaerobic metabolism result in increased hydrogen ion concentration and a drop in $\mathrm{pH}$ in crustacean hemolymph (Barrento et al., 2009; and references therein). Crustaceans have compensation mechanisms that act in response to acidosis through mobilization of buffer bases. However, during severe and prolonged hypoxia, the ability of an organism to compensate may be exhausted. When no further metabolic compensation occurs, the pH level will drop below the tolerated range and, as a result, the rates of enzymatic reactions, ionic and osmoregulatory controls, and cell membrane structure will be affected. Poor health, morbidity, and mortality have been reported to be correlated with low $\mathrm{pH}$ values in crustaceans (Whiteley and Taylor, 1992; Ridgway et al., 2006).

In laboratory experiments, Norway lobster (Nephrops norvegicus) exposed to water with low concentration of dissolved $\mathrm{O}_{2}\left(<20 \% \mathrm{O}_{2}\right.$-saturation) showed a sudden and rapid decrease in [Hc] (Baden et al., 1990). The length of time before the decline began depended on the $\mathrm{O}_{2}$ concentration. When lobster were exposed to $10 \% \mathrm{O}_{2-}$ saturation, an immediate reduction of their mean [Hc] 


\section{Table 4}

Ionic composition of hemolymph from snow and southern Tanner crabs under different experimental conditions. Ionic concentration values are means $( \pm 1$ standard error $[\mathrm{SE}]) . n=$ no. crabs sampled.

\begin{tabular}{|c|c|c|c|c|c|c|c|c|c|c|c|}
\hline \multirow[b]{2}{*}{ Species } & \multirow[b]{2}{*}{ Experimental conditions } & \multicolumn{10}{|c|}{ Ion concentration $\left(\mathrm{mmol} \mathrm{L}^{-1}\right)$} \\
\hline & & $\mathrm{Na}^{+}$ & $n$ & $\mathrm{~K}^{+}$ & $n$ & $\mathrm{Ca}^{2+}$ & $n$ & $\mathrm{Mg}^{2+}$ & $n$ & $\mathrm{Cl}^{-}$ & $n$ \\
\hline & Seawater from Bering Sea & 449 & - & 9.5 & - & 9.8 & - & 51.1 & - & 523 & - \\
\hline & Seawater from Sea of Okhtosk & 453 & - & 9.6 & - & 10.5 & - & 51.6 & - & 528 & - \\
\hline \multirow[t]{6}{*}{ C. opilio } & $\begin{array}{l}\text { Repeated pot hauls at long time } \\
\text { intervals }(>3 \text { days })^{1}\end{array}$ & & & & & & & & & & \\
\hline & Immediately after capture & $465(13)$ & 4 & $12.6(0.4)$ & 7 & $8.3(0.3)$ & 16 & $36.0(0.6)$ & 10 & $482(4)$ & 10 \\
\hline & After 3rd lift & $443(28)$ & 3 & $9.2(0.7)^{* *}$ & 6 & $8.0(0.4)$ & 8 & $34.0(1.5)$ & 8 & $469(17)$ & 8 \\
\hline & $\begin{array}{l}\text { Long-term starvation in the } \\
\text { crab pot ( } 55 \text { days })^{2}\end{array}$ & & & & & & & & & & \\
\hline & Immediately after capture & $399(15)$ & 7 & $10.8(0.5)$ & 7 & $8.2(0.4)$ & 7 & $35.7(1.5)$ & 7 & $482.8(19)$ & 7 \\
\hline & After starvation & $374(33)$ & 5 & $8.7(0.9)^{*}$ & 5 & $7.2(0.6)$ & 5 & $32.6(3.8)$ & 5 & $463(48)$ & 5 \\
\hline \multirow[t]{9}{*}{ C. bairdi } & $\begin{array}{l}\text { Repeated pot hauls at long time } \\
\text { intervals }(>3 \text { days })^{1}\end{array}$ & & & & & & & & & & \\
\hline & Immediately after capture & $472(5)$ & 4 & $13.0(0.8)$ & 7 & $7.7(0.3)$ & 18 & $33.8(0.7)$ & 10 & $477(5)$ & 10 \\
\hline & After 3rd lift & $388(78)$ & 3 & $8.2(2.1)^{*}$ & 6 & $7.5(0.5)$ & 7 & $30.8(2.2)$ & 7 & $444(28)$ & 7 \\
\hline & $\begin{array}{l}\text { Long-term starvation in the } \\
\text { crab pot ( } 25 \text { days })^{3}\end{array}$ & & & & & & & & & & \\
\hline & Immediately after capture & $406(25)$ & 3 & $11.3(0.6)$ & 4 & $8.2(0.3)$ & 5 & $27.0(1.1)$ & 5 & $413(38)$ & 5 \\
\hline & After starvation & $386(28)$ & 3 & $8.9(0.1)$ & 3 & $8.3(0.4)$ & 9 & $29.4(0.8)$ & 9 & $400(25)$ & 9 \\
\hline & $\begin{array}{l}\text { Long-term starvation in the } \\
\text { crab pot ( } 55 \text { days })^{2}\end{array}$ & & & & & & & & & & \\
\hline & Immediately after capture & $367(19)$ & 6 & $10.0(0.8)$ & 6 & $7.7(0.4)$ & 6 & $31.1(2.2)$ & 6 & $458(28)$ & 6 \\
\hline & After starvation & $370(23)$ & 5 & $9.5(1.1)$ & 5 & $7.7(0.3)$ & 5 & $32.4(2.7)$ & 5 & $447(34)$ & 5 \\
\hline
\end{tabular}

${ }^{1} 18$ May-12 June 2006, Bering Sea (area I).

219 September-12 November 2008, Sea of Okhtosk (area I).

37 July-2 August 2008, Bering Sea (area I).

* Significantly different from that of individuals sampled immediately after capture $(P<0.05)$, Student's $t$-test.

** Significantly different from that of individuals sampled immediately after capture $(P<0.01)$, Student's $t$-test.

by $65 \%$ of the initial value occurred within 4 days. Animals in water with $12 \%$ and $15 \% \mathrm{O}_{2}$-saturation first increased their [Hc] for 15 and 36 days, respectively. After those time periods, a rapid decrease in [Hc] occurred at a rate similar to the one recorded for lobster in water with $10 \% \mathrm{O}_{2}$-saturation. Mortality of animals during hypoxic experiments ranged from $40 \%$ to $100 \%$. Glycogen depletion in muscles and in the hepatopancreas of lobster also was seen after $\mathrm{O}_{2}$ deficiency, reflecting a shift to anaerobic metabolism (Baden et al., 1994). However, loss of functional hemocyanin in the hemolymph of lobsters during these hypoxic experiments (as indicated by a reduction in oxyhemocyanin concentration measured with a spectrophotometer) did not correlate with loss of blood copper. Baden et al. (1994) suggested that, under conditions of hypoxic experiments, the functional integrity of Hc molecules is damaged, leading to changes of the $\mathrm{O}_{2}$-binding properties of Hc. Their assumption seems reasonable because severe metabolic acidosis induces an increase in protein degradation because of activation of proteolysis and nonenzymatic hydrolysis of proteins.
In our experiments, respiratory acidosis, internal hypoxia, and anaerobic metabolism in crabs may have been caused by impaired gas exchange in damaged gills or exposure to air during handling on the deck. However, in our experiments, declines in $[\mathrm{Hc}]$ were not related to decreases in animal vitality. The highest decrease in [Hc] for snow and southern Tanner crabs was observed in the experiments with repeated pot hauls at long time intervals ( $>3$ days), during which the vitality of animals was high. In animals considerably weakened during repeated pot hauls at short time intervals ( $\leq 3$ days) or during prolonged air exposure, $[\mathrm{Hc}]$ was reduced to a lesser extent or not changed (Figs. 3, 4, and 5).

The rapid decline in [Hc] observed in our experiments was, therefore, unlikely to have been due to degradation of the protein as a result of respiratory hypoxia and severe metabolic acidosis. Additionally, SDS/PAGE showed no changes in the subunit composition of Hc's from snow crab and southern Tanner crab in our experiments. In individuals of both species of crabs, different proportions of the Hc subunits were sometimes observed, but these differences were not correlated with 
experimental conditions. Therefore, the structure of the Hc's remained unchanged in our experiments.

Changes in $[\mathrm{Hc}]$ in our experiments, therefore, were likely caused by physical and functional impairments that resulted from pot hauling. Changes in vitality of animals and $[\mathrm{Hc}]$ depended not only on the number of pot lifts but also on the time intervals between them. Decreases in $[\mathrm{Hc}]$ were related to high vitality of crabs. These observations indicate that the physiological imbalances caused by repeated pot hauls can be corrected if the time interval until the next haul is sufficiently long. It is also likely that the stress response involves changes in $[\mathrm{Hc}]$.

\section{Copper content in the hepatopancreas}

It has been postulated that copper metabolism in decapod crustaceans associated with degradation of $\mathrm{Hc}$ (during starvation or before molting) includes the processes of copper translocation to the hepatopancreas and storage in the form of complexes with glutathione and copper-binding proteins (Djangmah, 1970; Brouwer et al., 2002). Brouwer et al. (2002) showed that metabolism of the copper-binding protein metallothionein in the hepatopancreas of blue crab was related to molt stage. Metallothionein isoform 3 was present in premolt and softshell crab and was absent in hepatopancreas of intermolt crab. Emergence of this protein appears to coincide with a decrease in Hc synthesis and increase in Hc degradation.

In experiment 9, after starvation within a period of 55 days, a significant increase in mean copper concentration in the hepatopancreas of southern Tanner crab was found. We also observed a significant decrease in mean $[\mathrm{Hc}]$ in these crabs, compared with Hc levels in control animals immediately after capture. However, in experiments 6 and 7, which involved repeated pot hauls at short time intervals, there were no significant changes in hepatopancreas copper levels in snow and southern Tanner crabs that had reduced [Hc] (Table 3). Therefore, much of the copper that was released during Hc degradation caused by pot hauling did not accumulate in the hepatopancreas and was probably excreted from the body. This result may be explained by low levels of copper-binding proteins in the hepatopancreas of adult males of snow and southern Tanner crabs because they do not have periods of active synthesis and degradation of $\mathrm{Hc}$ associated with molt stage.

\section{Ionic composition of hemolymph}

Plasma ion $\left(\mathrm{Na}^{+}, \mathrm{K}^{+}, \mathrm{Cl}^{-}, \mathrm{Ca}^{2+}, \mathrm{Mg}^{2+}\right)$ concentrations were measured to examine ionoregulatory changes at the gills of affected crabs. The snow and southern Tanner crabs are typical of other stenohaline marine crustaceans in that their hemolymph is isosmotic with their environmental seawater but the ionic composition of their hemolymph can differ considerably from the composition of seawater around them (Prosser, 1973).
In the hemolymph of snow crab and southern Tanner crab, $\left[\mathrm{K}^{+}\right]$is considerably higher and $\left[\mathrm{Mg}^{2+}\right]$ is considerably lower than concentrations in the surrounding seawater.

Biochemical analysis of stress responses in crustaceans have shown that various stressors can alter ion concentrations in hemolymph and, therefore, that ions may be used as indicators of physiological stress (Stoner, 2012; and references therein). However, the exact mechanisms and physiological causes of ionic changes are usually difficult to explain. Several studies have reported increased $\left[\mathrm{Ca}^{2+}\right]$ and concentration of bicarbonate ion $\left(\mathrm{HCO}_{3}^{-}\right)$in crustacean hemolymph during aerial exposure, which may indicate the mobilization of calcium carbonate $\left(\mathrm{CaCO}_{3}\right)$ from internal sources, such as calcified exoskeleton to compensate for low $\mathrm{pH}$ (Taylor and Whiteley, 1989; Lorenzon et al., 2007). [ $\left.\mathrm{Mg}^{2+}\right]$ can be elevated in hemolymph of open-wounded crabs because of entry of magnesium-rich seawater (Uhlmann et al., 2009). Changes in $\left[\mathrm{K}^{+}\right],\left[\mathrm{Na}^{+}\right]$, and $\left[\mathrm{Cl}^{-}\right]$in hemolymph of crustaceans are highly variable with stress (Stoner, 2012; and references therein).

In experiment 1 , which involved repeated pot hauls at long time intervals, and in experiment 9, which investigated long-term starvation in pots, $\left[\mathrm{K}^{+}\right]$in hemolymph of snow crab and southern Tanner crab were significantly lower compared with $\left[\mathrm{K}^{+}\right]$in freshly caught crabs (Table 4). It should be noted that, in experiments 1 and 9, mean [Hc] in hemolymph of snow crab and southern Tanner crab were significantly lower compared with mean $[\mathrm{Hc}]$ in control crab immediately after capture.

An essential role is played by $\mathrm{K}^{+}$in the maintenance of the difference in electrical potential across the plasma membrane of a cell, typically referred to as the "membrane potential." That physicochemical regulatory function enables normal nerve impulse transmission, normal contraction of muscle fibers, and normal heart function. Interestingly, changes in the ionic composition of the hemolymph of crabs after repeated pot hauls were the same as changes in the ionic composition during long-term starvation, when metabolic rate and physical activity probably were reduced. However, the meaning of these changes needs to be studied.

\section{Effects of decompression on crab condition}

Changes in ambient pressure during lifts of crabs in pots to the water surface are an unavoidable adverse factor that affects the crabs. Studies of the blood circulation of brachyuran crabs, including snow and southern Tanner crabs, indicate that fluctuations of ambient pressure have the greatest effect on the blood flowing in the gills (Taylor, 1990). The phyllobranchiate gills of brachyuran crabs consist of 2 alternating rows of closely spaced, flattened lamellae that extend forward and backward from a median shaft. Each lamella consists of single layer of epithelial cells lining the cuticle. Pillar cells, which are located in the cellular layers in oppo- 
site walls of lamellae are connected to each other halfway in the hemolymph space. As common gill epithelial cells, pillar cells perform respiratory or salt transporting function depending on their localization within the gills and also are thought to play a role in stabilizing the lamellae against ambient and internal hydrostatic pressure (Compere et al., 1989; Johnson, 1980). Large fluctuations of ambient pressure can cause damage of the lamellae because the fragile pillar cells are not well adapted to withstand pressure forces. In our experiments, we observed disruption in the connections of pillar cells and collapse of the lamellae in gills of snow crab and southern Tanner crab that were subjected to repeated pot hauls (Fig 9).

The phyllobranchiate gills of brachyuran crabs are supplied with low pressure venous hemolymph. The afferent to efferent drop in pressure and mean internal pressure are generally only a few centimeters of water (Blatchford, 1971). During normal forward ventilation of gills by the scaphognathites, the lamellae tend to be inflated by a small positive transmural pressure, which is the difference between the above-ambient pressure in the lamellar hemocoel and subambient mean pressure in the branchial chamber in crab. Under these conditions, the resistance to hemolymph flow through the circulatory channels in the gills of crabs is low (McMahon and Burnett, 1990). However, any damage to gill structure could lead to a significant increase in gill resistance and consequently to increases in both the drop in pressure through the gills and in mean internal pressure (Taylor, 1990). Increased pressure in the injured gills likely would cause further gill damage and even greater impairment of gill function.

The main factor that determines the internal pressure in the gills of crabs is thought to be the total volume of internal fluid. One of the mechanisms for adjustment of a total fluid volume is regulation of urine release (Taylor, 1990). Hc is the major extracellular protein of crab hemolymph; hence, it is $[\mathrm{Hc}]$ that determines colloid osmotic pressure of blood plasma. In intermolt marine crabs, the small excess of hydrostatic pressure of hemolymph over colloid osmotic pressure drives passive filtration, which forms primary urine (Mangum and Johansen, 1975). The decrease in [Hc] may elevate the driving force for urine formation and, consequently, may lead to a decrease in total volume of internal fluid in crabs. In our experiments, blood sampling from crabs became more difficult after repeated pot hauls because the exhaust velocity of hemolymph from the cut was reduced. At the same time, the clotting time of hemolymph in experimental crabs was not changed or was increased compared with the clotting time in control animals (data not shown). These data indirectly indicate a decrease in blood pressure in the leg sinus that may be caused by a decrease in total volume of hemolymph.

A decrease in total blood volume through a decrease in $[\mathrm{Hc}]$ could not only prevent further gill damage but also reduce cardiovascular workload. However, a decrease in $[\mathrm{Hc}]$ causes a decline in the $\mathrm{O}_{2}$-carrying capac- ity of hemolymph that, in combination with impaired gas exchange in the damaged gills, could lead to a further decrease in supply of $\mathrm{O}_{2}$ to organs and tissues. Studies of the role of crustacean $\mathrm{Hc}$ in $\mathrm{O}_{2}$ transport have found complete oxygenation of $\mathrm{Hc}$ in postbranchial hemolymph but only partial deoxygenation of $\mathrm{Hc}$ in the tissues of normoxic, routinely active animals. The oxygenation level of $\mathrm{Hc}$ in the prebranchial hemolymph of resting normoxic animals (often called venous reserve) usually amounts to $50 \%$ or more of the $\mathrm{O}_{2}$ capacity of the hemolymph. Reduced $\mathrm{O}_{2}$ supply to the blood transport system or increased metabolic demand could result in depletion of the venous reserve. In normoxic conditions, the contribution of $\mathrm{Hc}$ to $\mathrm{O}_{2}$ transport significantly increases during physical exercises (e.g., locomotor activity) of animals (Truchot, 1992; and references therein).

In our previous studies of $[\mathrm{Hc}]$ in the hemolymph of red king crab (Paralithodes camtschaticus) in the Barents Sea and in the Sea of Okhtosk, $[\mathrm{Hc}]$ during the molt cycle was closely correlated with the volume of the limbs filled with muscular tissue (Moiseeva and Moiseev, 2008; Moiseeva and Moiseev, 2011). Those results also indicate that the $\mathrm{O}_{2}$ delivery system with $\mathrm{Hc}$ is required primarily to support high levels of locomotor activity of crabs. Therefore, reduction of $[\mathrm{Hc}]$ and a simultaneous decrease in locomotor activity of crabs could optimize blood flow in gills damaged by fisheries operations without a significant decrease in supply of $\mathrm{O}_{2}$ to organs and tissues.

Decompression, which results from a rapid lift of a pot to the surface of the water, is not a natural environmental stressor for crabs. However, our experiments showed that crabs quite successfully adapted to the damage of organs and tissues caused by decompression because they took advantage of existing physiological mechanisms. The gills of crabs are damaged often under natural conditions. In our experiments, in September-October 2010 in the northern Sea of Okhtosk, gross examination of tissues and organs revealed areas of melanization and necrosis in the gills of $40 \%$ of 50 freshly caught snow crab that had no sign of shell disease. In some crab, parts of some of the gills were absent (data not shown). Histological examination of organs and tissues has revealed histopathological changes in gills in $95 \%$ of snow crab with signs of shell disease (Ryazanova, 2006).

Gills serve an important role in the immune response of crustaceans. Aggregates of hemocytes and bacteria appear in hemolymph in response to microbial pathogens and then become trapped in the narrow hemolymph spaces of gills, where they are melanized and persist for a long time. The formation of hemocyte aggregates in blue crab that were injected with bacteria led to increases in vascular resistance across the gills and subsequent significant increases in the drop of hydrostatic pressure across the gill circulation (Burnett et al., 2006). Therefore, impairment of respiratory circulation apparently occurs often during infectious and noninfectious gill disorders of crabs. Crabs would be expected to possess 
mechanisms to cope with such impairments. The rapid degradation of Hc that we observed in our experiments may be one of these mechanisms. Increased degradation of blood protein, especially of Hc, has been observed in several euryhaline crab species during hyperosmotic stress (Gilles, 1977). In our experiments on snow and southern Tanner crabs, a similar phenomenon was observed in stenohaline crabs for the first time.

A single lift in a pot to the water surface apparently does not have significant effects on a crab. All of the crabs in our experiments survived at least 1 pot lift, the lift when they were captured. Therefore, experiments 8 and 9 on long-term starvation for 25 and 55 days, respectively, also can be considered for study of the delayed mortality of crabs after decompression. At the end of these experiments, all the animals were alive and had a high vitality. The negative effect of decompression significantly increases if the same crab is recaptured within a few days. However, the probability of such an event is very low. Crabs normally move actively in search of food; however, it is unlikely that discarded crabs will do so while they recover from their first capture.

On the basis of our experiments, a crab can survive (without serious harm) a recapture event that occurs more than a few days after its first capture. However, a decrease in $[\mathrm{Hc}]$ due to stress response would pose a challenge for snow and southern Tanner crabs. If its $\mathrm{O}_{2}$ transport system fails to meet all of the demands for energy during locomotion, a crab would not be able to sustain its normal level of activity. The reduction in [Hc] in crabs after a single lift in a pot obviously would depend on the initial condition of the animals and external factors. As shown in our experiments, this reduction in [Hc] can be very significant.

Several studies have shown that the synthesis of $\mathrm{Hc}$ in crustaceans depends on the quality of food eaten (Hagerman, 1983). It is assumed that food, not seawater, is the most important source of copper in crustaceans (Baden, 1990; and references therein). Copper reserves in the hepatopancreas may be used to reconstitute Hc, but significant accumulation of copper was not found in our experiments in the hepatopancreas of snow and southern Tanner crabs during degradation of Hc due to decompression. Therefore, the recovery of [Hc] in affected crabs would depend greatly on the availability and quality composition of the fodder base in their habitat.

\section{Conclusions}

Our research has shown that pot fishing has a significant effect on the physical condition of snow and southern Tanner crabs. Gill damage caused by ambient pressure differences and gas-bubble disease could have longterm effects on the vitality of crabs returned to sea from commercial catches after sorting. Both species of crabs have effective mechanisms for physiological adaptation to the adverse effects of pot fishing. The decrease in $[\mathrm{Hc}]$ that we observed in affected crabs is a long-term adjustment of the internal fluid volume of crabs that reduces pressure in damaged gills and optimizes respiratory circulation. The vital activity of crabs returned to sea after sorting of catches would depend on their condition before capture and the challenges presented by the specific environmental conditions at the time of their release.

Biochemical assays of Hc have proved to be a useful tool for the investigation of the effects of pot fishing on the physical condition of snow crab and southern Tanner crab. The plasticity of Hc content constitutes an efficient mechanism for crustaceans to cope with metabolic or environmental challenges. In our experiments, the greatest changes in $[\mathrm{Hc}]$ that resulted from stress response to impairment of blood flow in gills occurred in the most viable crabs. Therefore, $[\mathrm{Hc}]$ can be a useful indicator of the health of crabs in conditions that can lead to gill dysfunction.

\section{Acknowledgments}

This research was part of the studies of marine resources conducted by Russian Federal Research Institute of Fisheries and Oceanography, Moscow, Russia. We thank the crews of the vessels Sørvind and Evening Star for valuable assistance during experiments. We are especially grateful to the captain of the Shørvind, V. Gubsky, for his unfailing help and support. We appreciate very much the critical reading by $\mathrm{V}$. Bizikov of an earlier version of this manuscript.

\section{Literature cited}

Baden, S. P., M. H. Depledge, and L. Hagerman.

1994. Glycogen depletion and altered copper and manganese handling in Nephrops norvegicus following starvation and exposure to hypoxia. Mar. Ecol. Prog. Ser. 103:65-72.

Baden, S. P., L. Pihl, and R. Rosenberg.

1990. Effect of oxygen depletion on the ecology, blood physiology and fishery of the Norway lobster Nephrops norvegicus. Mar. Ecol. Prog. Ser. 67:141-155.

Barrento, S., A. Marques, P. Vaz-Pires, and M. L. Nunes. 2009. Live shipment of immersed crabs Cancer pagurus from England to Portugal and recovery in stocking tanks: stress parameter characterization. ICES J. Mar. Sci. 67:435-443.

Bell, T. A., and D. V. Lightner.

1988. A handbook of normal penaeid shrimp histology, 114 p. World Aquacult. Soc., Baton Rouge, LA.

Blatchford, J. G.

1971. Haemodynamics of Carcinus maenas (L.). Comp. Biochem. Physiol. A: Comp. Physiol. 39:193-202.

Borisov, V. V., V. Stepanenko, and V. F. Tolkacheva

2003. Processing technology of crab in the Barents Sea. In Red king crab in the Barents Sea, p. 299-311. PINRO Publ., Murmansk, Russia. [In Russian.] 
Bridges, C. R.

2001. Modulation of haemocyanin oxygen affinity: properties and physiological implication in a changing world. J. Exp .Biol. 204:1021-1032.

Brouwer, M., R. Syring, and T. Brouwer-Hoexum.

2002. Role of copper-specific metallothionein of the blue crab, Callinectes sapidus, in copper metabolism associated with degradation and synthesis of hemocyanin. J. Inorg. Biochem. 88:228-239.

Burnett, L. E., J. D. Holman, D. D. Jorgensen, J. L. Ikerd, and K. G. Burnett.

2006. Immune defense reduces respiratory fitness in Callinectes sapidus, the Atlantic blue crab. Biol. Bull. 211:50-57.

Comeau, M., and Conan, G. Y.

1992. Morphometry and gonad maturity of male snow crab, Chionoecetes opilio. Can. J. Fish. Aquat. Sci. 49:2460-2468.

Compere, Ph., S. Wanson, A. Pequeux, R. Gilles, and G. Goffinet.

1989. Ultrastructural changes in the gill epithelium of the green crab Carcinus maenas in relation to the external salinity. Tissue Cell 21:299-318.

Conan, G.Y., and M. Comeau.

1986. Functional maturity and terminal molt of male snow crab, Chionoecetes opilio. Can. J. Fish. Aquat. Sci. 43:1710-1719.

Dall, W.

1974. Indices of nutritional state in the western rock lobster, Panulirus longipes (Milne Edwards). 1. Blood and tissue constituents and water content. J. Exp. Mar. Biol. Ecol. 16:167-180.

Darnall, M. Z., K. M. Darnell, R. E. McDowell, and D. Rittschof. 2010. Postcapture survival and future reproductive potencial of ovigerous blue crabs Callinectes sapidus caught in the central Noth Carolina pot fishery. Trans. Am. Fish. Soc. 139:1677-1687.

deFur, P. L., C. P. Mangum, and J. E. Reese. 1990. Respiratory responses of the blue crab Callinectes sapidus to long-term hypoxia. Biol. Bull. 178:46-54.

Djangmah, J. S.

1970. The effects of feeding and starvation on copper in the blood and hepatopancreas, and on blood proteins of Crangon vulgaris (Fabricius). Comp. Biochem. Physiol. 32:709-731.

Dutil, J.-D., J. Munro, and M. Peloque.

1997 Laboratory study of the influence of prey size on vulnerability to cannibalism in snow crab (Chionoecetes opilio O. Fabricius, 1780). J. Exp. Mar. Biol. Ecol. 212:81-94.

Gilles, R.

1977. Effects of osmotic stresses on the proteins concentration and pattern of Eriocheir sinensis blood. Comp. Biochem. Physiol. A: Comp. Physiol. 56:109-114.

Giomi, F., and M. Beltramini.

2007. The molecular heterogeneity of hemocyanin: its role in the adaptive plasticity of Crustacea. Gene 398:192-201.

Hagerman, L.

1983. Haemocyanin concentration of juvenile lobsters (Homarus gammarus) in relation to moulting cycle and feeding conditions. Mar. Biol. 77:11-17.

Hagerman, L., and S. P. Baden.

1988. Nephrops norvegicus: field study of effects of oxy- gen deficiency on haemocyanin concentration. J. Exp. Mar. Biol. Ecol. 116:135-142.

Ivanov, B. G., and M. G. Karpinskiy.

2003. Mortality of crabs trapped in pots: snow crab in the northern Sea of Okhotsk. Problems Fisheries 4:590-607. [In Russian.]

Jadamec, L. S., W. E. Donaldson, and P. Cullenberg.

1999. Biological field techniques for Chionoecetes crabs. Alaska Sea Grant College Program Report AK-SG-99-02, 80 p. Univ. Alaska, Fairbanks, AK. doi:10.4027/bftcc. 1999.

Johnson, P. T

1976. Gas-bubble disease in the blue crab, Callinectes sapidus. J. Invertebr. Pathol. 27:247-253.

1980. Histology of the blue crab, Callinectes sapidus: a model for Decapoda, 440 p. Praeger, New York.

Kirichenko, S. G., O. A. Galutva, and V. F. Poluyaktov.

2005. Determination of some chemical elements by atomic absorption. In Quality, safety and methods of analysis of products from aquatic organisms. Guidelines for determining the content of toxic substances in products from aquatic organisms (L. P. Kopylenko, ed.), p. 3-6. VNIRO Publ., Moscow. [In Russian.]

Koblikov, V. N.

2004. On the mortality of Japanese red crab (Chionoecetes japonicus) in the crab pots and some aspects of the crab fisheries in the northern Japan Sea. Problems Fisheries 5:458-469. [In Russian.]

Laemmli, U. K.

1970. Cleavage of structural proteins during the assembly of the head of bacteriophage $\mathrm{T}_{4}$. Nature 227:680-685.

Lorenzon, S., P. G. Giulianini, M. Martinis, and E. A. Ferrero. 2007. Stress effect of different temperatures and air exposure during transport on physiological profiles in the American lobster, Homarus americanus. Comp. Biochem. Physiol., A: Mol. Integr. Physiol. 147:94-102.

Lovrich, G. A., and B. Sainte-Marie.

1997. Cannibalism in the snow crab Chionoecetes opilio (O. Fabricius) (Brachyura: Majidae), and its potential importance to recruitment. J. Exp. Mar. Biol. Ecol. 211:225-245.

Mangum, C. P., and K. Johansen.

1975. The colloid osmotic pressures of invertebrate body fluids. J. Exp. Biol. 63:661-671.

McMahon, B. R., and L. E. Burnett.

1990. The crustacean open circulatory system: a reexamination. Physiol. Zool. 63:35-71.

Mihailov, V. I., K. V Bandurin., A. V. Gornichich, and A. N.

Karasev.

2003. Commercial invertebrates of shelf and continental slope of the northern part of the Okhotsk sea. 284 p. Magadan NIRO Publ., Magadan, Russia. [In Russian.]

Moiseev, S. I.

2003. A study of effectiveness of different crab pots in coastal zone of the Barents Sea. In Bottom ecosystems of the Barents Sea. VNIRO Proceedings, vol. 142 (V. I. Sokolov, ed.), p. 178-191. VNIRO Publ., Moscow. [In Russian.]

Moiseev, S. I., S. A. Moiseeva, and A. M. Lapteva.

2012. Change of hemolymph parameters in Tanner crab due to the stress caused by fishing with crab pots. Problems Fisheries 13:125-144. [In Russian.] 
Moiseeva, S.A., and S. I. Moiseev.

2008. Relation between muscular tissue condition in limbs and hemocyanin concentration in the hemolymph of red king crab (Paralithodes camtschaticus) in the Barents Sea. Problems Fisheries 9:200-217. [In Russian.]

2011. Relationship between hemocyanin concentration in the hemolymph and filling of limbs with muscular tissues of the red king crab (Paralithodes camtschaticus) during postmolt period. Problems Fisheries 12:332-348 [In Russian.]

Nickerson, K. W., and K. E. van Holde.

1971. A comparison of molluscan and arthropod hemocyanin-I. Circular dichroism and absorption spectra. Comp. Biochem. Physiol. B: Comp. Biochem. 39:855-872.

Péqueux, A., A. C. Vallota, and R. Gilles.

1979. Blood proteins as related to osmoregulation in Crustacea. Comp. Biochem. Physiol. A: Comp. Physiol. 64A:433-435.

Prosser, C. L.

1973. Comparative animal physiology, $3^{\text {rd }}$ ed., $1011 \mathrm{p}$. W. B. Saunders Publ. Co., Philadelphia, PA.

Ridgway, I. D., A. C. Taylor, R. J. A. Atkinson, G. D. Stentiford, E. S. Chang, S. A. Chang, and D. M. Neil.

2006. Morbidity and mortality in Norway lobsters, Nephrops norvegicus: physiological, immunological and pathological effects of aerial exposure. J. Exp. Mar. Biol. Ecol. 328:251-264.

Ryazanova, T. V.

2006. Histopathological changes among the snow crab (Chionoecetes opilio) on the westkamchatkan shelf of the Okhotsk Sea. In Research of water biological resources of Kamchatka and of the northwest part of Pacific Ocean (Y. P. Diakov, ed.), vol. 8, p. 207-216. KamchatNIRO Publ., Petropavlovsk-Kamchatsky, Russia. [In Russian.]

2009. Development of bacterial infections and gas bubble disease in crabs owing to lifting in pots. In Research of water biological resources of Kamchatka and of the northwest part of Pacific Ocean (Y. P. Diakov, ed.), vol. 13, p. 95-100. KamchatNIRO Publishing, Petropavlovsk-Kamchatsky, Russia. [In Russian.]

Sainte-Marie, B., S. Raymond, and J.-C. Brêthes.

1995. Growth and maturation of the benthic stages of male snow crab, Chionoecetes opilio (Brachyura: Majidae). Can. J. Fish. Aquat. Sci. 52:903-924.

Senkbeil, E. G., and J. C. Wriston.

1981. Catabolism of hemocyanin in the American lobster, Homarus americanus. Comp. Biochem. Physiol. B: Comp. Biochem. 69:781-790.

Slizkin, A.G.

2010. Atlas of Russian Far East crabs and shrimps, 256 p. TINRO-Center Publ., Vladivostok. Russia. [In Russian.]

Slizkin, A.G., V.N. Koblikov, and E.R. Shaginyan.

2001. Snow crab, Chionoecetes bairdi Rathbun, of the northwestern Pacific: abundance dynamics, size composition and reproduction fautures. In Study of biology of commercial crustaceans and algae of Russia seas. Collected papers (B. G. Ivanov, ed.), p. 75-91. VNIRO Publ., Moscow [In Russian.]

Spicer, J. I., and S. P. Baden.

2001. Environmental hypoxia and haemocyanin betweenindividual variability in Norway lobster Nephrops norvegicus (L). Mar. Biol. 139:727-734.

Spicer, J. I., and J. O. Strömberg.

2002. Diel vertical migration and the haemocyanin of krill Meganyctiphanes norvegica. Mar. Ecol. Prog. Ser. 238:153-162.

Stoner, A. W.

2009. Prediction of discard mortality for Alaskan crabs after exposure to freezing temperatures, based on a reflex impairment index. Fish. Bull. 107:451-463.

2012. Assessing stress and predicting mortality in economically significant crustaceans. Rev. Fish. Sci. 20:111-135

Tallack, S. M. L.

2007. Escape ring selectivity, bycatch, and discard survivability in the New England fishery for deep-water red crab, Chaceon quinquedens. ICES J. Mar. Sci. 64:1579-1586.

Taylor, H. H.

1990. Pressure-flow characteristics of crab gills: implications for regulation of hemolymph pressure. Physiol. Zool. 63:72-89.

Taylor, E. W., and N. M. Whiteley.

1989. Oxygen transport and acid-base balance in the haemolmyph of the lobster, Homarus gammarus, during aerial exposure and re-submersion. J. Exp. Biol. 144:417-436.

Terwilliger, N. B.

1998. Functional adaptations of oxygen-transport proteins. J. Exp. Biol. 201:1085-1098.

Truchot, J. P.

1992. Respiratory function of arthropod hemocyanins. Adv. Comp. Environ. Physiol. 13:377-410.

Uhlmann, S. S., M. K. Broadhurst, B. D. Paterson, D. G. Mayer,

P. Butcher, and C. P. Brand.

2009. Mortality and blood loss by blue swimmer crabs (Portunus pelagicus) after simulated capture and discarding from gillnets. ICES J. Mar. Sci. 66:455-461.

van Tamelen, P. G.

2005. Estimating handling mortality due to air exposure: development and application of termal models for the Bering Sea snow crab fishery. Trans. Am. Fish. Soc. 134:411-429.

Vasilyev, A. G., and S. V. Klinushkin.

2011. Data on mortality of the triangle Tanner crab (Chionoecetes angulatus) in fishing traps in the northern part of the Sea of Okhotsk. Problems Fisheries 12:566-575. [In Russian.]

Whiteley, N. M., and E. W. Taylor.

1992. Oxygen and acid-base disturbances in the hemolymph of the lobster Homarus gammarus during commercial transport and storage. J. Crust. Biol. 12:19-30. 